\title{
ESSAY
}

\section{WHEN THE LAW DOESN'T COUNT: THE 2000 ELECTION AND THE FAILURE OF THE RULE OF LAW}

\author{
KUM LANE SCHEPPELE ${ }^{\dagger}$
}

In the movie Monty Python and the Holy Grail,' the unconvincinglooking but immensely self-confident King Arthur and his rag-tag band of knights gallop on their imaginary horses through the wild forest in search of the Holy Grail. Encountering one obstacle after another, our heroes (for they are clearly meant by the logic of storytelling to be our heroes) ${ }^{2}$ overcome these challenges by making the most of the distinctly unroyal conduct of quibbling, distracting the opposition, and sometimes just running away. At one point in their quest, however, the path of Arthur's little band is physically blocked by giant human figures dressed in forbidding black armor, screaming in chorus. Their leader introduces them as "Knights Who Say NI!" The Knights' main weapon is to shout "NI!" (also sometimes "Peng,"

† Professor of Law and Sociology, University of Pennsylvania. Many people provided constructive comments on short notice while the ashes from this election still smoldered. I am particularly grateful to Steve Burbank, Cary Coglianese, Richard Fallon, Howard Gillman, Ed Hartnett, Seth Kreimer, Frank Michelman, Martha Minow, Serguei Oushakine, and the Constitutional Law and Legal Theory Workshop at the Harvard Law School for clarifying the arguments, pointing out contradictions, and generally engaging in the ultimate act of collegiality-taking early ideas seriously and nurturing them with care. If I could not take on board the full implications of all of the perceptive comments, it is certainly not the fault of the commentators.

'MONTy' PYThon AND THE Holy GRAil (Python Pictures 1974).

V Vadimir Propp discusses the structural elements of folktales and identifies that a folktale might start, for example, with a seeker-hero leaving home in search of something. The seeker-hero then meets with challenges along the way that he overcomes with the help of a magical element, and the meeting of the challenge in this way is what allows others to recognize him as the hero that he is and allows him to achieve the goal that he seeks. VLADIMIR PROPP, MORPHOLOGY OF THE FOLKTALE 3942, 60-61 (Laurence Scott trans., 2d ed. 1968).

"These are not elements of a folktale as described by Propp, and their humor derives from the fact that they run counter to the logic of storytelling, where the challenges are supposed to be met with feats of cleverness, bravery, and magic. Id. at $60-62$. 
"Neee," and "Wom") at the unhappy group in particularly shrill voices, causing our heroes to recoil and cover their ears. And, following fairytale convention, the Knights will not let our heroes pass until the heroes perform a brave feat. The brave feat the Knights have in mind? Our heroes need to bring them something. ${ }^{4}$ And what do the Knights demand? "We want," they say, "a shrubbery!"

As storytelling rules dictate, our heroes go off in search of shrubbery. And, after overcoming more obstacles designed to test their courage and strength, ${ }^{6}$ our heroes find the prize: a rather attractive-looking planting with a white picket fence all around. Pleased with themselves, they deposit the shrubbery before the Knights, who are somehow still dissatisfied. The reason for their dissatisfaction? The Knights Who Formerly Said NI! are now "the Knights Who Say Neeeow ... wum ... ping!," and they now claim that "we are no longer contractually bound by any agreements previously entered into by the Knights Who Say NI!" What do the Renamed Knights now want? "You must get us [pregnant pause] another shrubbery!" "7

The movie-going audience, together with Arthur and his Knights, realize at this point that they are in an endless loop. The Knights Who Say NI! (or Neeow ... wum ... ping!, as the case may be) will never be satisfied; their demands are endless and they will always want something that our heroes haven't done. This violates fairytale conventions, which require that our heroes be tested, that they prove their merit, and, when they have met the challenge, that they be then, by right, allowed to pass. But the Knights Who Say NI! don't seem to know the formula. They are caught outside the standard story line in an endless loop of their own. From the sidelines, we can shout, "They've done what you asked-now let them pass!" But the Knights Who Say NI! scream the magic words that are designed to disable their hapless victims so loudly that they drown out everything else.

From the moment that Election 2000 failed to produce a clear

${ }^{4}$ One of the feats that a hero can be asked to perform is to fill an especially' difficult request, one of which can be a task of "supply" or "manufacture." Id. at 61 .

"MONTY PYTHON AND THE HOLY GRAIL, supra note 1.

'Or at least that is how the story is supposed to go. In the movie, our heroes go off and attempt to torture an old woman to disclose where they might find shrubberies, until they are stopped in their efforts by an enterprising young shrubber, who comes along and offers to sell them some. Id. Propp suggests that the performance of the feat is supposed to be achieved by magical agents, one of which is that people can appear out of nowhere to help the hero. PROPP, supra note 2, at 45.

MONTY PYTHON AND THE HOLY GRAIL, supra note 1. 
result on election day, Al Gore and his modern-day knights set off on a journey through Florida's legal forest, encountering one obstacle after another in their effort to "count every vote." Fairytale convention dictated that, after proving his courage and his strength by acquiring the various court permissions he won along the way in the state of Florida, Gore should be allowed to recount the ballots to see if, in fact, he had won." This is one reason why it seemed particularly unfair when the U.S. Supreme Court suddenly stopped first the count and then the election, announcing an ambitious set of criteria for recounting that would have required much "additional work" to specify" - and yet the Supreme Court's own timing gave Gore no opportunity to meet the new standards. The decision left supporters of both $\mathrm{Al}$ Gore and George W. Bush with a sense that the drama didn't have a proper conclusion." After the immense tension of the thirty-six days when the election hung in the balance, the whole votecounting contest was simply called off by a Supreme Court decision. The election ended with the spectacle of a group of television reporters and legal commentators frantically trying to read and

"After a campaign that even some supporters said lacked a coherent message, he not only found one but has stuck to it: Count every vote." Katharine Q. Seelye \& Melinda Henneberger, Cantesting the Vote: The Gore Camp; In Storm's Eye, Gore Stays Upibrat, Aides Say, N.Y. TIMES, Dec. 10, 2000, \$1, at 1.

"Bush supporters might counter with a fairytale version of their own that would have a similarly irresistible logic. George W. Bush (the hero in this version) is venturing through the wild forest with his supporters, having already found the Holy Grail-the victorious election result. But then a pursuer (Al Gore) makes his appearance and this pursuer chases our hero in an effort to steal the Grail. If our hero really' is a hero, then he should be rescued from pursuit through magical means. PROPP, sufma note 2, at 56-57. Our hero may throw things in the way of his pursuer, and if our hero is truly a hero, these random things will spring up into fearsome obutacles (reversals, stays), id. at 57 , or, alternatively, our hero may be given a new appearance that allows him to triumph with the magical assistance of a helper (James Baker, Dick Cheney, the Supreme Court), $i d$. at 62.

"Bush v. Gore, 121 S. Ct. 525, 532-33 (2000) (per curiam). The U.S. Supreme Court required that statewide standards be adopted "after opportunity for argument" along with "practical procedures to implement them." Id.

"For elaboration, see infra Part IV where I argue that we still don't know by now how many votes Bush won Florida, nor can we confidently say what Florida election Iaw, as it was applied in the 2000 election, is. Continuing the analogy, the ending of Monty Python and the Holy Grail, which is devoted largely to challenging all of these storytelling conventions, is actually rather similar. At the end of the film, the (modern day) British police ride up to where the strangely dressed actors are charging over a hill and arrest them all for breach of the peace. The drama that was all along set in the Middle Ages suddenly turns out to be a crime story in modern Britain. The film ends abruptly as King Arthur and his knights are taken into custody. MONTY PYTHON IND THE HOLY GRAL, supra note 1. 
summarize on-air a sixty-page set of decisions that did not have a clear result. The case was reversed and remanded back to the Florida Supreme Court for proceedings consistent with the opinion ${ }^{12}$-but there were no further procedures that could have been consistent with the opinion except a Florida Supreme Court judgment saying that nothing could be done. The best reporters and legal commentators could do immediately was to say that they thought Gore might have conclusively lost but that they would wait for Gore to announce what he thought the decision meant. Gore conceded the next day. The Florida Supreme Court, whose critical decision the U.S. Supreme Court found wanting, conceded the day after that. ${ }^{13}$

From childhood tales, we know how these stories are supposed to turn out. In one of the two usual scenarios, the hero is supposed to be killed off as he performs the feats he has been asked to accomplish. If he is cut down as he tries to meet the challenges he has been given, he is exposed as a false hero. ${ }^{1+}$ Alternatively, in the other scenario, if the hero satisfies the requirements laid down, then he must be allowed to pass, since he is the true hero after all. ${ }^{15}$ It is not supposed to happen that the hero satisfies the requirements only to find that he has to go back and start all over again ${ }^{16}$ with a new set of rules. (And even if there are new rules, they are not supposed to be announced when there is no longer time to play the game under them.) Once the Grail-seekers have found the shrubbery as they were originally asked to do, they should not have to go off to hunt for more bushes that

${ }^{12}$ Bush v. Gore, 121 S. Ct. at 533.

${ }^{13}$ "On the date of the subject election, the Florida Election Code did not provide the elements necessary for a resolution of the disputed issues, based on the constitutional parameters expressed by the United States Supreme Court. Accordingly, relief cannot be granted, and this case is dismissed." Gore v. Harris, No. 00-2431, slip op. at 2 (Fla. Dec. 14, 2000) (order on remand), available at http://election2000.stanford.edu/00-2431USSCRemandOrd.pdf. Some of the judges amplified their anguish in a set of decisions released on December 22. See Gore v. Harris, 773 So. 2d 524 (Fla. 2000). Justice Leander Shaw's concurring opinion captured the fairytale logic of the election cases: "Admittedly, the present scenario is surreal: All the king's horses and all the king's men could not get a few thousand ballots counted. The explanation, however, is timeless. We are a nation of men and women and, although we aspire to lofty principles, our methods at times are imperfect." Id. at 529-30 (Shaw, J., concurring).

${ }^{14}$ Someone can be exposed as a false hero when he fails to complete a task that has been set for him. PROPP, supra note 2, at 62.

15 "The hero is ... recognized by his accomplishment of a difficult task" and then, when he is properly recognized as the hero that he is, "the hero is married and ascends to the throne." Id. at 62-63.

${ }^{16}$ Sisyphus notwithstanding. Thanks to Steve Burbank for reminding me. 
weren't on the list in the first place, especially when the order announcing new requirements comes from the same people who gave the initial instructions and who now claim that they are no longer bound by the standards that they first announced. Or, in the case of the election, once the ground rules are set so that the candidate who gets the most votes wins, the contest shouldn't shift to guessing what magic formula would allow the votes to be counted.

That's fairytale logic. But it is also the logic of the rule of law. Legal requirements should not keep shifting as a quest for justice goes on. Of course, in any moderately complex legal system, judgments by lower courts sometimes change when an appeal results in conflicting interpretations of law (or in reversals and remands) because the rule of law typically guarantees a certain course of reexamination to check the results an initial court reaches. Each of these shifts can ultimately result in a change in who concretely wins at different stages of the process, but such changes should also result in a clarification of what the law required at the time that the contested actions were performed. Ideally, also, the winner at the last stage should be the one that had the best of the principles everyone knew were in play all along. The process of successive legal judgments in the same case should not keep shifting the ground out from under the litigants so that, in the end, the case is decided by rules that did not seem to be in existence when the case was begun or that had been discarded along the way as irrelevant only to be picked up as decisive later on. Law shouldn't be a game of "gotcha."

Regardless of one's political views on which party had the better policy positions in the election and the better legal arguments in the subsequent court cases, both the Bush and Gore sides were disserved by the public spectacle of a court system that could not fix a stable set of principles that got clearer as appeals went on. Gore, in particular, found himself in a succession of "Catch 22s," in which the next logical legal step required completion of some subsequent step that he could not attempt until he had already taken the next logical step. ${ }^{17}$ In the end, the Catch 22 dilemmas proved fatal for Gore because, when confronted with an impossible next step, the status quo at the point of impossibility always wins. And George W. Bush's most powerful resource during the thirty-six-day rollercoaster ride was that he had the status quo going for him. The legitimacy of Election 2000, however, is clouded because it is hard to describe the process that

${ }^{17}$ Sir JOSEPH HELLER, CATCH 22 (1961). 
occurred as one that deeply respected legality though it was decided by America's highest court, which in the end pulled a constitutional rabbit out of the election-litigation hat. The various decisions issued by multiple courts and handed down with great speed in November and December 2000, taken together, do not reveal a process befitting a government committed to the rule of law. In the end, as Justice Stevens, dissenting from the Supreme Court opinion that ended the recounts, argued:

It is confidence in the men and women who administer the judicial system that is the true backbone of the rule of law. Time will one day heal the wound to that confidence that will be inflicted by today's decision. One thing, however, is certain. Although we may never know with complete certainty the identity of the winner of this year's Presidential election, the identity of the loser is perfectly clear. It is the Nation's confidence in the judge as an impartial guardian of the rule of law. ${ }^{18}$

At the start of the twenty-first century, America has portrayed itself as a state that makes a commitment to the rule of law something it claims for itself and also demands of other states. Unlike some other constitutions, ${ }^{19}$ however, the U.S. Constitution does not have an explicit rule-of-law clause. ${ }^{20}$ The United States therefore has no explicit rule-of-law jurisprudence in the sense that has become typical in a number of other constitutional democracies. One lesson of modern history, however, is that the basic requirements of the rule of law are not optional in a constitutional state. Germans learned this lesson especially well, having had their apparently "model" Weimar Constitution collapse in the most horrific unconstitutionality of our time. ${ }^{21}$ The rise of Hitler through what seemed to be perfectly legal methods is now widely regarded as having cast a long shadow over the "calamitous positivism" of Weimar jurisprudence." The German Basic

${ }^{18}$ Bush v. Gore, 121 S. Ct. 525, 539 (2000) (Stevens, J., dissenting).

${ }^{19}$ See infra note 24 (listing constitutions with specific rule-of-law clauses).

20 The American Constitution has some rough equivalents-for example the Due Process Clause of the Fourteenth Amendment and the prohibition against ex post facto laws in Article I, Section 9. But to the extent that the Due Process Clause covers some of the same territory as the principles I am talking about here, it does so primarily in the area of criminal law.

${ }^{21}$ See generally ElLEN KENNEDY, Constitutional FalluRE: CarL SCHMTtT IN WEIMAR (forthcoming 2002).

${ }^{22}$ As David Currie writes, references to Recht in German law have been seen by some constitutional scholars as a reaction against "calamitous positivism," binding judges in cases of conflict between the literal wording of the statutes and their senses of justice to "follow justice rather than law." DAVD CURRIE, THE CONSTITUTION OF 
Law that rose from the ashes of the victims of Nazi Germany, not surprisingly, now explicitly embodies the idea of a Rechtsstaat (often translated, though imperfectly, as the rule of law). ${ }^{23}$ Other countries that have been through historical horrors of their own have included rule-of-law clauses in their constitutions as well. ${ }^{24}$ In short, rule-of-law

THE FEDERAL REPUBLIC OF GERMAAIY 119 (1984).

"Set Ernst-Wolfgang Böckenförde, The Origin and Development of the Concept of the Rechtsstaat, in STATE, SOcIETY AND LIBERTY: STUDIES IN POLITICAL THEORY AND Constitutional LAW 47 (J.A. Underwood trans., 1991). Article 20 (entitled "Basic principles of state order, right to resist") of the Basic Law of the German Federal Republic is also helpful:

(1) The Federal Republic of Germany is a democratic and social federal state.

(2) All state authority emanates from the people. It is being exercised by the people through elections and voting and by specific organs of the legislature, the executive power, and the judiciary.

(3) Legislation is subject to the constitutional order; the executive and the judiciary are bound by law and justice.

(4) All Germans have the right to resist any person seeking to abolish this constitutional order, should no other remedy be possible.

GRUNDGESETZ [GG] [Constitution] art. 20 (F.R.G.), available at http://www.uniwuerzburg.de/law/gm00000_.html.

The central importance of this Article can be seen in the fact that it is constitutionally unamendable. Id. art. 79(3). For discussion of the Rechtsstaat principle, see CURRIE, supra note 22, at 18-20; DONALD KOMMERS, THE CONSTITUTIONAL JURISPRUDENCE OF THE FEDERAL REPUBLIC OF GERMANY, 36-37 (2d ed. 1997).

"Article 2(1) of the postcommunist Hungarian Constitution states:

The Republic of Hungary is an independent, democratic constitutional state. Uogallám, a direct translation into Hungarian of Rechtsstaat, is translated here as "constitutional state."]

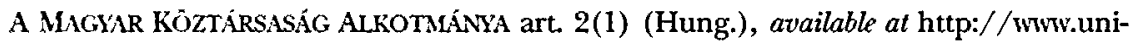
wuerzburg.de/law/hu00000_.html.

Article 1 of the postsoviet Russian Constitution states:

The Russian Federation-Russia shall be a democratic federal rule-of-law state with the republican form of government.

KONST. RF 1993 art. 1 (Russ.), available at http://www.uni-wuerzburg.de/law/ rso0000_.html.

The post-apartheid Constitution of South Africa, in Chapter 1, Section 1 (entitled "Founding Provisions") declares:

The Republic of South Africa is one sovereign democratic state founded on the following values:

(a) Human dignity, the achievement of equality and the advancement of human rights and freedoms.

(b) Non-racialism and non-sexism.

(c) Supremacy of the constitution and the rule of law.

(d) Universal adult suffrage, a national common voters roll, regular elections and a multi-party' system of democratic government, to ensure accountability, responsiveness and openness.

S. AFR. CONST., ch. 1, \$ 1 (S. Afr.), available at http://www.uni-wuerzburg.de/law/ sfloouo0..html. 
clauses in modern constitutions are far from unusual, and there is a developing sense of basic judicially recognizable principles of a ruleof-law state that are fundamental to a constitutional order, a set of principles of surprising resilience across constitutional systems.

What I will suggest in this Essay is that Americans can learn something from looking abroad at times like this-not just to see narrowly whether other countries use paper ballots or some more modern technology in their elections, but instead to see what basic principles of state are crucial for creating a constitutional democracy that operates under the rule of law. And, toward this end, it is helpful to see how others have self-consciously defined what it means to have a rule-of-law state. Election 2000 reveals that Americans have not

The postcommunist Constitution of Slovenia provides in Article 2 (entitled "Rule of Law, Social State"):

Slovenia is a state governed by the rule of law and is a social state. USTAVA art. 2 (Slovn.), available at http://www.uni-wuerzburg.de/law/si00000_html.

The Constitution of Switzerland (enacted in 1998 when Switzerland was having a major national debate over its role in the Holocaust) provides in Article 5 (entitled "Rule of Law"):

(1) The law is the basis and limitation for all activities of the state.

(2) State activity must be in the public interest and proportional.

(3) State institutions and private persons must act in good faith.

(4) The Confederation and the Cantons do respect international law.

BUNDESVERFASSUNG art. 5 (Switz.), available at http://www.uni-wuerzburg.de/law/ sz00000_.html.

The post-Franco Constitution of Spain states in Article 9 (entitled "Rule of Law"):

(1) The citizens and public powers are subject to the Constitution and the legal order.

(2) It is the responsibility of the public powers to promote conditions so that liberty and equality of the individual and the groups he joins will be real and effective; to remove those obstacles which impede or make difficult their full implementation, and to facilitate participation of all citizens in the political, economic, cultural, and social life.

(3) The Constitution guarantees the principle of legality, the normative order, the publication of the norms, the non-retroactivity of punitive provisions which are not favorable to, or which restrict individual rights, legal security, and the interdiction of arbitrariness of public powers.

CONSTITUCIÓN art. 9 (Spain), available at http://www.uni-wuerzburg.de/law/ sp00000_html.

The postcommunist Constitution of Romania in Article 15 (entitled "Rule of Law, No Retroactive Law") provides:

(1) All citizens enjoy the rights and freedoms granted to them by the

Constitution and other laws, and have the duties laid down thereby.

(2) The law acts only for the future, with the exception of the more favorable penal law.

CONSTITUTIA art. 15 (Rom.), available at http://www.uni-wuerzburg.de/law/ ro00000_html. 
incorporated into constitutional jurisprudence principles that have been widely accepted elsewhere.

The rule of law in American jurisprudence is customarily associated, as Richard Fallon has pointed out, with historicist, formalist, or process-based ideas about law. While these "strands" of thought each have their distinctive elements, all start from preference for and deference to positive law, particularly statutes, and in fact they can be seen as interpretive principles for understanding positive law. Should a statute be read in its historical context? Or according to its plain words? Or in light of what present procedures require? The rule of law is about stabilizing meanings of positive law, wherever possible. This is perhaps one reason why the rule of law is often used in a merely decorative manner in American constitutional jurisprudence-precisely because it doesn't say more about what substantive goals one ought to try to achieve through law.

Courts outside the United States, however, have had to develop an explicitly substantive doctrine of the rule of law to animate rule-of-law clauses in their constitutions. Comparative analysis reveals that ruleof-law clauses are not used primarily to decide among principles of interpretation, but instead to diagnose when a statute has gone badly wrong and needs to be supplemented by principles taken from elsewhere in the law. The rule of law, then, emerges in comparative constitutional jurisprudence not as an interpretive tool, but as a diagnostic one. As such, it appears, perhaps surprisingly, exactly at the moment when a court is about to declare that a statute is

Fallon identifies four strands in American constitutional jurisprudence on the rule of law: (I) historicist understandings that preserve the stability of the law through a steady reliance on original intent; (2) formalist understandings that emphasize the way in which formal rules facilitate advance planning through fairly warning subjects of the law and of what is required of them; (3) legal process understandings that cmphasize procedural fairness and public reason in the particular case; and (4) subutantive understandings in which the moral intelligibility of the law is ensured through rule-of-law norms. Fallon emphasizes the tensions among and incompatibilities in these various strands, and provides ample empirical evidence from an extensive survey of American constitutional case law to show that all are in wide use. In his sketches toward a general theory of the rule of law, Fallon emphasizes that a subutantive conception of the rule of law would be harder (and more unwise) to integrate into a general theory. Historical, formal, and procedural understandings are more constructively used for the basis of such a theory, in his view. I hope to show that the conception of the rule of law that one can find from looking outside the American cuntext is closer to Fallon's substantive strand and that it is possible to develop a subutantive conception of the rule of law that could add to Fallon's model. Richard $\mathrm{H}$. Fallon.Jr., "Tht' Rutle of Law" as a Concept in Constitutional Discourse, 97 CoLuM. L. REv. I (1947). 
unconstitutional. Rule of law becomes the device through which a court justifies its need to look elsewhere in the law for guidance about what to do.

In analyzing Election 2000, I will argue that the problems we saw in Florida stemmed from a deeply flawed statute on which different courts along the way tried to put pressure. What resulted was a great deal of legal flip-flopping from one decision to the next since the different courts that heard the various election challenges could not agree on how to fill in the blanks or remove the contradictions from the law, something that courts in countries with explicit rule-of-law clauses in their constitutions do by developing strong substantive conceptions of what those clauses mean. The end result in the American election was that it was, I argue, decided according to no discernible law at all.

\section{THE RULE OF LAW AS A SUBSTANTIVE CONSTITUTIONAL PRINCIPLE}

There is a good historical reason why the United States doesn't have a rule-of-law clause in its Constitution. Rule-of-law clauses didn't become standard equipment in constitutional design until the postWorld War II period, when the world had seen the horrors of constitutional regimes run amok. For the previous generations of constitution-writers, and certainly in the late eighteenth century when the U.S. Constitution was written, separation of powers and lists of rights were the mechanisms of choice for reducing the chances that the institutions of state would amass powers for use against the state's own citizens. There was a great faith that representative institutions of republican government, embedded in a system of separation of

${ }^{26}$ In what follows, I am going to commit the unforgivable comparative law sin of assuming that the English "rule of law," the German Rechtsstaat, the Hungarian jogallam, and other similar nationally specific legal ideas with their own distinctive differences can be discussed more or less interchangeably. Let me give a Wittgensteinian defense. If words are as words do, then I think that the clear historic and national differences among these various terms have been deeply eroded by the modern jurisprudence of different constitutional courts. The rule-of-law (or equivalent) clauses of contemporary constitutions, despite their diverse treatments in national histories of legal philosophy, are invoked in remarkably similar cases. My' guess is that constitutional court judges are far more likely at this point to borrow from transnational constitutional experience than from their own national histories, and this is what gives the constitutional jurisprudence across national boundaries such coherence. The new rule-of-law jurisprudence has far fewer distinctive national qualities than the intellectual histories of their various national concepts would indicate. But this is an empirical claim, subject to examination by review of the decisions. 
powers in which different constituencies and different majorities would ensure that no unchecked body could run roughshod over the rest, would have no opportunity or warrant for engaging in violations of citizens' legally protected interests on a substantial scale. Judicially enforceable guarantees of rights could correct individual-level abuses or temporary excesses.

Obriously, however, the constitutions that embodied ideas about separation of powers and respect for rights were not enough to prevent the descent of apparently constitutional states into "regimes of horror" in the twentieth century. ${ }^{27}$ The regimes responsible for some of the most horrific twentieth-century abuses of human rights were regimes that started with written constitutions embodying just these features (or at least constitutions that had moved in that direction from previously more absolutist regimes). But these constitutions failed nonetheless to prevent their governments from committing mass atrocities. Nazism famously grew out of the weaknesses in the Weimar Constitution, ${ }^{2 *}$ and Austrian fascism grew in the same soil that had nurtured the first European constitution to institutionalize a strong form of judicial review. The Russian

${ }^{2}=$ St Kim Lane Scheppele, Constitutional Interpretation After Regimes of Horror (May 2000) (unpublished manuscript), available at http://papers.ssm.com/ paper.tat?abstract_id=236219. In that paper, I use Julia Kristeva's conception of horror and its associated process of abjection, see generally JULLA KRISTEVA, POWERS OF Horror: AN ESSII ON ABjection (Leon S. Roudiez trans., Columbia Univ. Press 1489) (1980), to mark those regimes that have carried on such comprehensive abuse against their own citizenries that, in constructing a new regime, those who lived through the old one can only look back on the bad old days with the particular combination of familiarity and disgust. recognition and rejection, that defines horror.

The intellectual debates that surrounded the collapse of the Weimar Constitution flirted with the idea that law should be nothing more than a tool for the esercise of power, a view famously attributed to Carl Schmitt. For Schmitt, "the energing Nazi legal order was superior to its liberal democratic rivals in part because fascist Germany's heary reliance on vague, open-ended indeterminate legal provisos alone allegedly gave full expression to the centrality of an arbitrary willfulness that was thought to constitute the unavoidable essence of all legal experience." William $\mathrm{E}$. Scheuerman, Introdution to THE RULE OF LAW UNDER SIEGE 3 (William E. Scheuerman ed., 1496). Others who argued against Schmitt nonetheless at first took skeptical views of law and its ability to do anything other than provide post hoc rationalizations for decisions reached on other grounds. Law, when confronted with state sovereignty and the power it represented, had no defense, as Franz Neumann argued. See FRLNZ

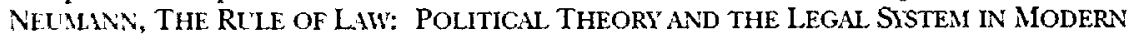
Suc IETY $*$ (1986) ("So far as the sovereignty of the state extends there is no place for the Rule of Law:"). But the experience of fascism brought at least some of the early Fr.mhfurt school back from the legal abyss after the war. See Scheuerman, supra, at 2 (contrasting Neumann and Kirchheimer's "appreciation for a series of liberal legal and political institutions" with their colleagues' "apocalyptic theorizing"). 
Revolution swept aside the tentative moves toward parliamentary government expressed in the 1906 Russian Constitution and Japanese aggressions in Asia were carried out under the Meiji Constitution that, while far more absolutist than its Western European counterparts, also institutionalized a bicameral parliament with more than cosmetic powers. Contemplating the human devastation wrought by fascism, Stalinism, and the aggressions leading to the Second World War, constitutional drafters after the war tried to find new constitutional mechanisms beyond separation of powers and lists of rights to bolster the ability of "post-horror" states to say "never again."

Post-War, post-horror constitutions as a result typically include guarantees of a particular form of accountable government, longer lists of rights (some of them constitutionally unamendable), ${ }^{3,1}$ the entrenchment of powerful judicial review in an independent institution located outside the normal judiciary, ${ }^{31}$ and, often, rule-oflaw clauses. ${ }^{32}$ In postsoviet Europe and in post-apartheid South Africa, these mechanisms have been further institutionalized to the point where they are now the standard operating equipment of the new constitutionalism. While much has been written about rights and judicial review in the new constitutions, I want here to explore briefly what has become of these new rule-of-law clauses, both because I believe that they tell us something important about what constitutionalism had lacked before and also because the growing consensus over the new meaning of the rule of law helps us to understand what went disastrously wrong in the American election of 2000.

There is a strand of jurisprudential discussion that turns up

${ }^{29}$ For example, the German Basic Law pronounces in Article 20(1), "The Federal Republic of Germany is a democratic and social federal state." GG art. 20(1). The postsoviet Hungarian constitution in Article 2(1) provides, "The Republic of Hungary' is an independent democratic, constitutional state." A MAGYAR Közrársisíg ALKOTMÁNYA art. 2(1).

${ }^{30}$ Article $79(3)$ of the German Basic Law makes certain rights unamendable features of the German constitutional order. GG art. 79(3). Other constitutional governments institutionalize this principle in different ways, for example, through the requirement that statutes infringing on rights in any way be passed as "constitutional laws" with supermajorities.

${ }^{31}$ Herman SCHWARTZ, THE Struggle fOR CONSTITUTIONAL JUSTICE IN POSTCOMMUNIST EUROPE (2000) (pointing out that all of the postcommunist states adopted constitutional courts).

${ }^{32}$ See supra note 24 (citing examples). Japan is, of course, an exception to much of this given the influence of Americans in the constitutional drafting process and the consequent prominence of American ideas in the design of Japan's post-War institutions. 
frequently in English-language discussions of the rule of law, particularly in the positivism versus natural law debates that were carried on in the pages of the Harvard Law Review between H.L.A. Hart and Lon Fuller and the subsequent elaboration of these ideas in the crucial books they wrote. ${ }^{33}$ Of course, these debates occurred in the shadow of fascism and its association with positivism, and one of H.L.A. Hart's major contributions to jurisprudence can be seen in his effort to democratize and re-moralize positivism to the point where it was possible for positivism to become intellectually respectable again. Still, seen from the vantage point of early twenty-first-century constitutionalism, it is Fuller's discussion of the inner morality of law that has better captured what has happened to the practical operation of the rule of law as courts have understood it when they have interpreted their new rule-of-law clauses.

Fuller identified this inner morality of law with a series of principles, the violation of which would cause a legal order to fail the morality (and hence the legality) test. Such violations included failures to notify the affected party of the rules she is to follow, abuses of retroactive legislation which cannot guide action in advance, rules that require conduct that the party cannot perform, and frequent changes in law. ${ }^{34}$ These were moral principles and not just technical requirements because they were, in modern parlance, subjectifications of the law. They represented not just formal mandates to the lawmaker but (to use the language available to Fuller at the time) also criteria that must be met in order for the subjects of law to have fidelity toward law. The inner morality of law was "inner" in two senses: it was inner in the sense of being the deep go-without-saying animating principle of a legal order (where "inner" is the opposite of "superficial" or "obvious"), and it was inner in the sense of being a mental state with which legal subjects approach the law (where "inner" is the opposite of "externally generated" or "externally

Compary. H.L.A. Hart, Positivism and the Separation of Law and Morals, 71 HARV. L. REV, 593 (1958) (describing and critiquing distinctions between law as it "is" and law as it "ought" to be), with Lon L. Fuller, Positivism and Fidelity to Law-A Reply to Professor Hort, 7I HLIRV. L. REV. 630, 631 (1958) [hereinafter Fuller, Positivism and Fidelity to Law] (rejecting positivist thinking on the grounds that its "intellectual clarity is specious and that its effects are, or may be, harmful"). See generally H.L.A. HART, THE CONCEPT OF LAW (1961) (specifying a positivist theory of law); LON L. FULLER, THE MOR LLITY OF LAW 3 (1964) [hereinafter FULLER, THE MORALITY OF LAW] (explaining that only" after a clear definition of "morality" has been established can we hope to understand the ways in which law and morality interact).

Fulier, THE MORALITY OF LAW, supra note 33, at 38-39. 
imposed"). And, as I will argue, the rule of law has become, in comparative constitutional jurisprudence, the constitutional device through which both of Fuller's intuitions have become incorporated into the daily decisions of constitutional courts. The rule of law captures both this internal logic of law and also the incorporation into the legal order of the legitimate expectations of the legal subject. ${ }^{35}$

At one level, rule-of-law clauses seem redundant in a modern constitution. The successful creation of a constitutional order owes at least something to the acceptance of the rule of law as a valid principle of state and so the existence of a functioning constitution all by itself should bear witness to the reality of the rule of law." The constitutionalization of politics brings formerly unchecked power under law and so expands the jurisdiction within which legal constraint operates. A constitutional state, then, seems necessarily a state under the rule of law. Moreover, a constitutional state might be seen as an improvement on "mere" rule of law. Rule of law as a historical-legal principle had, as we have seen, a tendency to fall into formalism and value-insensitive positivism, without more substantive principles operating alongside it.

The rule-of-law jurisprudence of the new constitutional courts indicates that the basic principles of a constitutional government do not exhaust the ideas that might be read into the rule of law. One might have expected this if "mere" rule-of-law principles were superceded by a grander ambition to constitutionalize government so

${ }^{35}$ On the private law side, the work of Austrian Friedrich Hayek has been enormously influential in a libertarian defense of the rule of law. He argues that the spontaneous order of the market required a stable framework of law within which individuals can predictably arrange their affairs. For Hayek, law could perform this function only when it was abstract and general, known, certain, and prospective with equal application to all who would call upon it. F.A. HAYEk, THE CONSTITE TION OF LIBERTY 296 (1960). Hayek's view of the rule of law is what I will call an objectivist or externalist view-one that sees laws as existing outside the legal subject, toward which the legal subject must orient her actions as an external constraint. Fuller's view is quite different, for he sees the morality of law as something that legal subjects bring to law as a regularized set of expectations which a legal system should meet. Law can theretore be constrained by something external to it-the convergence of expectations of legal subjects.

${ }^{36}$ There is, however, a tradition in writing about the rule of law, in which the rule of law is identified with the rigid adherence to statutes, so that constitutionalism then poses a challenge to the rule of law or can be seen only as a supplement to the rule of law that is different in kind from ordinary rule-boundedness. As András Sajo notes, "Constitutionalism can partly diminish the rule of law's one-sided inflexibility and its alienation from life, because it uses not only the legal means of restricting power and it carries substantive values...." ANDRÁs SAJÓ, LIMITING GOVERINIENT: AN INTRODUCTION TO CONSTITUTIONALISM 208 (1999). 
that a constitutional state obviously incorporates the basic principles of the rule of law. In fact, however, rule-of-law clauses are quite often called upon now to do real constitutional heavy lifting above and beyond the simple idea that a constitutional government is a government of laws. Clearly, maintaining both a functioning constitution and institutionalized judicial review does not fix all of the problems of legality that the rule of law identifies, or else one would expect that rule-of-law clauses would be far more ornamental than they are. But rule-of-law clauses have found a wide variety of serious uses. Most interesting for our purposes, the core uses of rule-of-law clauses are also deeply consistent across constitutional governments.

The main idea at stake in much contemporary comparative ruleof-law jurisprudence is the principle that law itself cannot be used as a tool of abuse against those subject to the law. This is not the same as the proposition that government must operate through law or that the institutions of state must be constrained by law, both of which are already included in the ordering principles of a constitutional state. The rule of law's new form-that it checks whether law itself is being used to cause harm-suggests that it is a principle responding to a different set of problems and a different history.

How can law itself cause harm? Law itself can cause harm when its contradictory instructions to the legal subject make it impossible for the legal subject to orient her actions toward the law. Law itself can cause harm when it changes so rapidly that the legal subject is thrown off guard and therefore must be continually wary of being caught up in legal changes that she would have no way of knowing. Law itself can cause harm when a legal provision is interpreted one way on one day and a contradictory way on the next so that the legal subject cannot readily work out which interpretation will apply to her. Law itself can cause harm when the pervasiveness of legal rules traps the legal subject in overregulation, such that she is forced to choose between obeying law \#1 or obeying law \#2 since both cannot be simultaneously followed. Law itself can cause harm when it is retroactively applied (and yet the legal subject is held responsible for actions committed when the law was not in place) or is impossible to follow (and yet the legal subject is punished for not following it). In short, law itself can cause harm when law is the device through which legal subjects are thrown off balance, caught in a state of uncertainty about what their responsibilities are, and then held accountable in a system made public to legal subjects in the moment that they are held responsible under it. 
The new rule of law in constitutional regimes that have seen altogether too much of this sort of legal abuse steps in to protect legal subjects from the harsh abuses of legality that disregards legitimacy. The new rule of law takes the legal security of the legal subject to be a primary aim of a constitutional order. The new rule of law, therefore, takes the point of view of the legal subject and asks what effect the law has on her, what legal surprises she can reasonably be expected to bear, and what legitimate expectations the legal subject has to use in her own defense against the abusive operation of law itself. The new rule of law does not just issue commands to legal subjects, but considers the effects of such commands on the production of legal subjectivity. Do contradictory, retroactive, rapidly changing, inconsistent, gap-filled, abusively interpreted laws help to create a constitutional consciousness that is consistent with respect for the legal order? Or does law like that operate by fear and coercion alone to extract compliance from legal subjects? The new rule of law guides the operation of law itself toward the first and eschews the second in the full recognition that a constitutional regime can only be secure and complete if the legal subjects of that regime are motivated to comply with the law by more than fear of punishment when they violate it. A constitutional regime needs to do more than subject power to law; it needs also to encourage and respect a constitutional consciousness in the subjects of the law.

This is not always what the rule of law has meant. In the eighteenth and nineteenth centuries, the dominant political dilemma that constitutions sought to correct was the problem that the king was subject to no law at all. "Rule of law" under those circumstances was primarily an argument that the king and institutions of state had themselves to be bound by the law that they made for others. The fundamental equality before the law of all citizens (including those in positions of state power) was the rule-of-law battle fought when it was still not taken for granted that those who made the law could also be held to be subject to it.

In contemporary constitutional regimes, that idea is taken for granted in principle if not always in practice. Innovations in rule-oflaw thinking have moved on, pulled by new, or newly extreme, forms of state abuse. In the late twentieth and early twenty-first centuries, new constitutional regimes have had to struggle with the fact that they inherited a legal legacy in which the state used the law itself to control and harass the population, not just incidentally as a tactic of governance but as a crucial element of state policy toward its own 
citizens. ${ }^{7}$ Fascism and state socialism, for example, embraced law as the device that would allow citizens to be sorted, manipulated, and ultimately controlled. The extraordinary positivism of both forms of regime allowed either morally despicable or multiple contradictory laws to be passed, and those who became subject to these laws were met with much formal legal procedure, much of it designed to remove any humanity from the individual caught in the law's claws. What the twentieth century revealed in more extreme ways was that the repertoire of state abuse includes not just arbitrary and legally groundless actions (the worry of eighteenth- and nineteenth-century constitution writers) but also the insistence on impossibly elaborate legal precision and the arbitrary filling of legal gaps. When courts played "gotcha" with the law, citizens could be manipulated, subjugated, and thrown off guard without defense because they were subject to impossibly contradictory and immensely tangled legal regulation. With such a track record for law, law could hardly be associated with justice. So the idea of the rule of law needed to be adjusted to allow for the permissible escape from abusive law as well as for the more usual legal constraint by legitimate law. In short, the rule of law as a principle of the new constitutionalism has started to recognize that legality alone does not entail legitimacy and that the faithful operation of law itself is no excuse for abuses that occur in law's name.

' Not that this is a historically new phenomenon. E.P. Thompson's thoughtful esploration of the rule of law in England under the Black Acts shows that a huge number of newly created capital offenses were created precisely as class crimes, meant to apply to some but not all of the population. See E.P. THOMPSON, WHIGS AND HUNTERS: THE ORIGIN OF THE BIACK ACT 190-218 (1975) (describing the politics of the Black Act and tracing its evolution from an emergency Act to one aimed specifically at those people who were suffering economic and social oppression). The specific list of new crimes offended a conception of the rule of law in which the law should be applied equally to all, not just in letter but in spirit. But, as Thompson found, much to his own surprise, the rule of law still existed in the sense of guaranteeing a certain stability and predictability of court challenges that made it promible for those targeted by the law to defend themselves in ways that they would otherwise not have been able to do. In his moving tribute to the rule of law at the end of his book, this Marxist historian describes the rule of law as "an unqualified human good." I . at 266 . The sense of the rule of law that he discovered-providing not just for formal equality of legal provisions but providing primarily structures that are stable enough for people to understand how they may defend themselves-is similar in spirit to what I will be developing here.

One could, of course, say the same about South Africa during the days of apartheid, since the creation and maintenance of the racialist regime was done exactly through the passage of and enforcement of statutes. Apartheid was a deeply legal structure and not a lawless one. 


\section{A. Understanding the Rechtsstaat}

The German case is perhaps the most visible and influential one in which law was a tool of abuse and now, therefore, has to meet higher standards of justification. Much has been made of the fact that Hitler operated, at least at first, with much attention to the formal legality of his actions, ${ }^{39}$ and that there was a sort of legal precision about ensuring that the laws corresponded with state action, if not beforehand then at least after the fact. ${ }^{40}$ One standard view about the rise of German fascism is that German lawyers and judges were too positivist and formalist in their legal philosophies to resist the onslaught of fascism that started through constitutional means. ${ }^{41}$ As Böckenförde notes, the substantive idea of the Rechtsstaat had been hollowed out by positivism for decades before the collapse of a constitutional sensibility, leaving the German constitutional system with no defense. ${ }^{42}$

Even after this history of law abuse, however, the German Basic Law of 1949 nonetheless reintroduced the concept of the Rechtsstaat, as a way of ensuring that a moral force be given to basic principles of legality. What else could they do? After all, the remedy for a state that has abused law is not to have no law when the state is reconstituted in more democratic and responsive form. But the drafters of the German Basic Law surely did not want to reproduce the formalism of prior conceptions of the rule-of-law state. ${ }^{43}$ The German Constitutional Court has made the Rechtsstaat one of the basic foundational principles of German constitutional jurisprudence, and

39 In 1930, Hitler said:

The National Socialist movement will try to achieve its aim with constitutional means in this state. The constitution prescribes only the methods, not the aim. In this constitutional way we shall try to gain decisive majorities in the legislative bodies so that the moment we succeed we can give the state the form that corresponds to our ideas.

David Dyzenhaus, Legality and LegitimaCy: CARL Schmitt, HaNS KeLSEN AND HERMANN HELLER IN WEIMAR 22-23 (1997) (citation omitted).

${ }^{40}$ Lon Fuller's discussion of the statute retroactively legitimating the Roehm Purge is illustrative of this use of law. Fuller, Positivism and Fidelity to Law, supra note 33 , at 650 .

${ }^{41}$ See DYZENHAUS, supra note 39 , at 5 ("[L]egal positivism, while not exactly paving the way for Nazism, offered no legal resource which could be used to resist a fascist seizure of power in Germany.").

${ }^{42}$ Böckenförde, supra note 23 , at 58-59.

43 See id. at 66 ("The change from a 'formal' to a 'material' concept of the Rechtsstaat arose out of a tendency that first appeared during the final years of the Weimar Republic: namely, the abandonment of judicial positivism."). 
it is anything but formalist. ${ }^{14}$ Instead, the elaboration of the rule of law as a constitutional principle is at least as much about when a judge is justified in invoking constitutional principles to understand (or invalidate) statutes as it is about ensuring integrity of the formal legal order in general.

The Soraya case produced what is perhaps the German Constitutional Court's most sweeping statement of what the rule of law means in contemporary German jurisprudence. ${ }^{45}$ In this constitutional complaint resulting from a judgment in a libel case, the Constitutional Court had to decide whether a decision of an ordinary court to add a remedy to the civil code when the plain language of the civil code excluded such a remedy was a violation of the constitutional right of the party ordered to undertake the remedy. At the outset, it would seem that an advocate of the rule of law would say that, of course, a judge cannot add a remedy where it is flatly forbidden by statute. On the facts of the case, ${ }^{46}$ however, it was troubling that the civil code failed to provide a remedy for such an egregious breach. Upholding the ordinary judge and allowing the remedy upset the predictability of the private law and required special justification. A purely formalist reading of the rule of law would have counseled against it. But instead, the German Constitutional Court took the leap and extended constitutional principles to override the literal wording

"S'S' CLRRIE, supra note 22, at 18-20 (explaining the fundamental role of the Ruclltsitat in judicial review); KoMmers, supra note 23, at $36-37$ (same).

Entscheidungen des Bundesverfassungsgericht [Federal Constitutional Court] 34 (1973), 269, translated in RUDOLF SCHLESINGER ET AL., COMPARATIVE LAW 627 (5th ed. 1988) [hereinafter Soraya Case].

"The case involved the Princess Soraya, ex-wife of the Shah of Iran, who had sued a German newspaper for publishing an alleged interview with her. The interview revealed, or at least appeared to reveal, very private facts about the princess's life. In fact, the transcript was fictitious; the interview had never occurred. The newspaper neser checked the account of the freelance journalist who had claimed to have interviewed the princess, though the newspaper later published a brief retraction aning that the interiew was a complete fake. The princess sued the newspaper, but the German Civil Code prevented money damages from being awarded in cases where the harm was merely dignitary and did not infringe on some property right of the plaintiff. Nonetheless, the trial court had awarded money damages, and the newspaper brought a constitutional complaint to the Constitutional Court, claiming that constitutionally guaranteed freedom of the press was violated by this deviation from the literal words of the Code. There were two strong constitutional principles on the wher side, however: the right of human dignity and the right to the development of personality of the indiridual who was harmed. So even though this was a private law matter, there were strong constitutional interests on both sides of the case. Id. at 62728. 


\section{of the civil code in this case, ${ }^{47}$ explicitly invoking the Rechtsstaat principle in the Basic Law:}

The judge is traditionally bound by the Gesetz (written law). This is an inherent element of the principle of separation of powers, and thus of the rule of law. Our Constitution, however, [in the Rechtsstaat-or ruleof-law-clause] . . . has somewhat changed the traditional formulation by providing that the judge is bound by "Gesetz und Recht" [i.e., written law" and (other) law]. [Recht is also sometimes translated as justice.] According to the generally prevailing view, this implies the rejection of a narrow positivistic approach predicated solely upon the written law.... Under certain circumstances there can be law beyond the positive norms enacted by the State-law which has its source in the constitutional legal order as a meaningful, all-embracing system, and which functions as a corrective of the written norms.... The judge's task is not confined to the ascertainment and implementation of decisions made by the legislator; he may be called upon, through an act in the nature of a value judgment ... to bring to light and to realize in his decisions those value concepts which are immanent in the constitutional legal order, but which are not, or not adequately, expressed in the language of the written laws. In performing this task, the judge must guard against arbitrariness; his decision must be based upon rational argumentation. He must make it clear that the written law fails to perform its function of providing a just solution for the legal problem at hand. Where this is so, the gap thus found is filled by the judge's decision in accordance with practical reason and the "community's established general concepts of justice."

On first pass, this may sound like the opposite of the rule of law because the judge has the power to move beyond the positive law to give voice to norms that are "immanent in the constitutional legal order," unsettling what the positive law literally says. But immediately,

${ }^{47}$ The court allowed the remedy of money damages, weighing the claim of freedom of press against the constitutionally protected right of the development of personality. The court also went to great lengths to show that the particular provision of the civil code that the newspaper was urging the court to read literally had been subject to academic criticism almost from the moment of its publication, and that courts in other countries in general rejected such a limitation of remedies. In addition, the court noted that the civil code itself embedded a personality right elsewhere, so that the private law and not just the constitutional law recognized the claim on the other side of the newspaper's case. Finally, the court noted that this case, while laying out general principles that would allow constitutional logic to apply to the private law, also carried limits. Only when there was this sort of strength of moral claim on one side and the absence of defense on the other, and when the civil law incorporated the principles supporting the nonliteral claim and when there had been this history of criticism of the civil law provision and the absence of support in comparative law, could the court be justified in departing from the rules laid down. Id. at $636-38$.

Id. at 635-36 (citations omitted) (second bracketed alteration in original). 
this power is qualified by outlining the practical responsibilities of the constitutional judge as she does this. Checking statutes against constitutional norms is a well-defined exercise of judicial power in a constitutional legal system because the judge is required to specify clearly' the legal problems to be remedied (in this specific case, the gaps in the law) and then to invoke "practical reason" about justice that are located not just in the court or in the text but in the broader community. This means that the judge is constrained not only by a theory of constitutional interpretation or by having the appropriate attitude toward the text of the law, such as it is. Instead, the judge is constrained also by her responsibilities to those to whom the law is directed-specifically the litigants, but also those who form the community into which the decision comes as an intervention in a concrete legal dispute.

In a situation in which the positive law fails to concretely recognize important values expressed elsewhere in the law, the ruleof-law principle, as elaborated in the Soraya case, instructs the judge not to consider the situation in a purely mechanical way. If the constitution requires that the positive law be supplemented or even changed, the judge must follow constitutional principles in doing so, while taking extra steps to ensure that the alteration of the positive law is not arbitrary, is accompanied by rational argument and is clear. These responsibilities are part of the constitutional order that grants the constitutional judge her power. The judge must be able to account for what she has done in a way that takes into account the legitimate expectations of the litigants and also appeals to constitutional values that clearly predate the action that is being judged. And then, finally, the norms the judge applies must be immanent in the law also." In doing all of this, the judge must constantly consider whether this decision can be justified to these litigants as well as to this community on the basis of principles clearly in

"While the idea of practical reason may introduce more trouble than it fixes in American jurisprudence, this idea has a special resonance in German jurisprudence because the idea of the Rechtsstaat had its origins during the Enlightenment in the triumph of reason over theocratic or despotic ideas about the state. It is therefore a more helpful and determinate idea in the German intellectual context. Bōckenförde, vapra note 23 , at 52 .

The Soraya case suggests that the values must be immanent not only in the constitutional order of values but also in the system of statutes that regulate the matter in question, even if the positive law says nothing directly on the matter. See Soraya Case, upra note 45 , at 633 (analyzing the addition of a right to the development of personality to the Civil Code in the 1950s). 
evidence before the decision was made. In short, the judge is to be guided by a responsibility to the audience for the decision and not just to the requirements of the text. ${ }^{\text {.1 }}$

In the Soraya case, the German Constitutional Court used the Rechtsstaat principle not to justify living within the plain words of the statute but precisely to justify intervention to undermine the literal meaning of the civil code. But doing this was clearly recognized by the Court as an exceptional act, subject to a higher burden of justification than would typically be the case. In acting apparently to unsettle the law, however, the constitutional judge had to look to the constitutional principles at stake, to the history of that provision of the civil code, to societal developments since the code was written, and even beyond domestic law to the way that such issues were resolved elsewhere. It may be, as the Constitutional Court thought in the Soraya case, that the more settled principles of law were the ones that the statute did not literally give voice to but were instead principles that were more broadly embodied in the hierarchy of constitutional values. $^{52}$

Rule-of-law principles give weight to the certainty and predictability of the law. Usually that means following the statutes as written. But occasionally-very occasionally-the argument may be made that a statute, taken literally, undermines settled expectations and widely understood public values more than it gives voice to them. And a rule-of-law judge cannot be so bound to the literal wording of the law that she misses the broader constitutional point. But even constitutional law cannot be used as a tool of abuse. If the constitution requires something where the positive law would seem to

51 One advantage of considering the German construction here is that it may allow Americans to see more clearly the issues of judicial power in a constitutional order without immediately collapsing them into questions of interpretation-whether strict construction, Framers' intent, or a normatively driven legal theory of first principles. The German debate focuses more clearly on the responsibilities of the judge in a constitutional order regardless of the method of constitutional analysis the judge favors. Of course, all standards, including nonarbitrariness, rational argumentation, and clarity give rise to interpretive problems of their own, but they have a rery different function in the German constitutional order than theories of interpretation have in the American one. They explain the obligations of the judge to the ultimate audience for the decisions, not the relationship of the judge to the text.

${ }^{52}$ The right of human dignity and the right to the development of personality, both of which were also given meaning in different provisions of the civil code, took precedence here over the claim by the newspaper that the remedy had not been written into the statute. The case also implied that the freedom of expression that the newspaper enjoyed did not have such strong protection in a case such as this in which the newspaper had published a complete fabrication without checking its source. 
indicate the opposite, filling in the legal gap must be done in such a way that the legitimate expectations of the litigants and the broader community are not themselves violated in the course of correcting a constitutional violation. This is not the old positivist conception of the rule of law speaking. It is a conception of the rule of law with a great deal of positive substance.

Of course, meeting the expectations of litigants and the broader community sounds all well and good, except for the fact that it is usually impossible. If the litigants could have agreed on general principles for resolving their dispute, they wouldn't be seeking an answer from a court. And if there were neutral principles that everyone could agree upon, we would have found them by now. So what could it mean that courts are supposed to look at the effects of the law on the litigants and the broader community to work out when a statute is abusive in present form and needs to be constitutionally supplemented?

The answer to this question is not going to come in the form of a general principle, but instead can be found in a careful weighing of the case-specific, all-things-considered context. Here, the Constitutional Court's reasoning in the Soraya case gives us some clue about how this can be done. In the Soraya case, the Court obviously disappointed the newspaper, which thought it was on firm ground, in opposing a penalty that was not provided for in the civil code. But it also was probably not surprising to the newspaper that legal consequences followed from publishing a false account that it had never checked. So while, in general, finding a remedy where none is written is something a court should not do, finding a remedy where the absence of one is truly odd is not so striking. Here, the newspaper had a strong positivist legal defense-the law did not provide a remedy for the plaintiff. But the newspaper was on morally shaky ground and, given the strong protections of the right of human dignity and the right to the development of personality in German constitutional law, it was therefore on constitutionally shaky ground as well. It would be hard to imagine anyone claiming that the newspaper had a right to publish falsehoods in a situation in which it had not made the most elementary inquiries about their truthfulness. Whatever conception of freedom of the press one has, it probably comes with at least some ideas about the responsibility of an institution with such great social power to engage in at least minimal attempts to check the facts that it prints. It seems a blind spot in German positive law that would allow the newspaper to escape liability 
in that case..$^{53}$ The Court justified its decision by pointing to decades of academic criticism of this flaw in the statute, noting that most other similar countries in fact provided remedies in a case like this, that the rights vindicated by the remedy were embedded not only in the constitution but in the civil code as well, and that the specific egregious conduct of the newspaper could not have been reasonably expected to be without consequence. It is just such an extraordinary case, when a statute has missed something that constitutional principle seems to require, that the constitutional principle can supplement or substitute for the statute without adding a new rule-oflaw violation. But these judgments cannot be made on the basis of broad principles pulled out of the air. Instead, they need to be made by considering closely just why the positive law may have failed in the particular case and providing reasons that are multiple, overlapping, and reliant on principles that everyone can recognize as preexisting the dispute.

\section{B. Defining the Rule of Law in Postcommunist Constitutional Law}

One finds a similarly thick and similarly anti-positivist rule-of-law conception in postcommunist societies as well, precisely because they too have experienced the disaster that results from believing that positive law is necessarily deeply legitimate. In the Soviet Union and its satellites, the signature legal innovation of the Stalinist era was the spread of show trials, perfectly scripted events in which the law appeared to be scrupulously followed and the evidence seemed to be perfectly clear. ${ }^{54}$ One could not fault show trials for their lack of attention to law, taken superficially. But of course, they were deeply antilegal demonstrations of the raw unchecked power of the state

${ }^{53}$ The Soraya case was not met with uniform joy in the German legal community, though the court relied on a long-standing history of criticism within the legal community of the concrete statutory provision in making its argument. The criticism was not about the result; even critics of the court did not defend the newspaper's conduct. The criticism was about the difficulties of limiting the principle to just the sort of case that the Soraja case represented. The subsequent history of the Sorrya jurisprudence has shown that the Constitutional Court did not intend for its decision to mean that positive law was under a general threat and, in fact, the German Constitutional Court has done this sort of thing quite rarely. For a summary of the criticism of the Soraya decision in English, see CURRI, supra note 22, at 116-21.

${ }^{5}$ See generally ALAJOS DORNBACH, THE SECRET TRLAL OF IMRE NAG' (1994) (detailing the way in which the "post-revolution regime fashioned 'legal means' to subvert the popular will"); GEORGE H. HOdOS, SHOW TRIALS: STALINIST PURGES IN EASTERN EUROPE, 1948-1954 (1987) (detailing the history of show trials against communists during the early postwar years in the soviet satellite nations). 
because they depended on tortured prisoners agreeing to invented facts.

Outside of these public displays of soviet legality, anti-legalism through superficial adherence to law continued in many ways great and small. The typical legal problem of state socialism was not the absence of law but, rather, its stunning, coercive pervasiveness in daily life. Most soviet-style governments were characterized by an "overregulation" which seemed endemic to the soviet conception of the state. There was not just one law that applied in a particular matter but a dozen-each with contradictory implications so that it would be difficult if not impossible to follow all the laws simultaneously. With so much law around, the ordinary person could not help but break at least some of it; there were so many contradictory rules and regulations that following one almost necessarily meant breaking another. ${ }^{5 /}$ Such overregulation also gave enormous power to those who had the discretion to enforce the law, ${ }^{56}$ because they chose which laws to emphasize and which to ignore when laws conflicted. When the laws don't form a coherent order, one may get the appearance of law but the experience of abuse because it is up to the discretion of the state official which particular rule takes precedence at the particular moment. In the newly democratic regimes emerging from soviet domination, a substantively strong constitutional idea animating the rule of law is one of the hardwon accomplishments of the new legal order. ${ }^{37}$

Postsoviet constitutional courts, particularly those in East-Central Europe, have made serious use of their rule-of-law clauses, animated by this history of abuse of formal law. But they have made use of these

S't' Elemer Hankiss, The Loss of Responsibility, in THE POLITICAL RESPONSIBILITY OF INTELLECTLALS 29, 46 (Ian Maclean et al. eds., 1990) ("East European societies are notoriously and hopelessly overregulated ... creat[ing] a chaotic situation where there are already too many contradictory and self-contradictory regulations.").

"Sir gruerally István Rév, Uncertainty as a Technique of the Exercise of Power: An Atproarle to the Question of Transition, 29 WORLD FUTURES 47 (1990).

Jirí Pribzin noted that in the Czech Velvet Revolution of 1989:

The revolutionary vocabulary, besides its other features, was accompanied by a legal positiristic vocabulary demanding the re-establishment of legality, due process of law and generally binding impartial procedures. Legal positivism and a formal legalist approach had a strong critical force because qualities of law such as the regularity, foreseeability, security, iterability, or integrityusually mentioned by legal positivists in their functionalist understanding of sfitems of positive law-became important values defending individual autonomy and security.

Jiři Přibán̆, Legitimacy and Legality After the Velvet Revolution, in THE RULE OF LAW IN CENTR1L EUROPE 29, 45-46 (Jiứ Püibáñ \& James Young eds., 1999) (citation omitted). 
clauses in anything but a formalistic way. Poland's Constitutional Tribunal, which had to operate until 1997 without a fully revised constitution, read practically a whole way of legal life into the rule-oflaw clause that was added to the constitution as part of a package of amendments in 1989. The Constitutional Tribunal grabbed the first opportunity to interpret the rule-of-law clause to forbid the retroactive application of laws and to guarantee rights. ${ }^{58}$ In 1993, for example, every decision in which the Constitutional Tribunal declared a statute to be unconstitutional invoked the rule-of-law clause. ${ }^{59}$ The rule-of-law clause in the transitional Polish constitution was filled in quickly with a set of real substantive values, and the core idea in the set was that the law itself could not be used as a tool of abuse. As one of the justices of the Polish Constitutional Court, writing with an American legal scholar, noted, "The Rechtsstaat ('state ruled by law') principle, rooted in nineteenth-century German legal culture, maintains that positive law should be consistent with fundamental rules of justice, fairness, and equity." Whether or not the Rechtsstaat meant this in nineteenth-century Germany is beside the point; what is important is that the Polish Constitutional Tribunal in fact believed that this is what it meant for a constitutional state to be ruled by law. Ironically, as in the Soraya case, the principle is invoked most often in Poland just when a statute is about to be declared unconstitutional, or when positive law is found wanting for failure to give voice to more general principles of constitution-based justice. A purely positivist and formalist reading of the rule of law would counsel just the opposite in those cases.

In Slovenia, too, the rule-of-law clause has also been invoked very frequently in ruling on the constitutionality of legislation. The ruleof-law clause there has been held to require "a coherent legal system, free of contradictions," that "legal postulates for the treatment and conduct of legal subjects [are] determined in advance or should at least be determinable."'2 Moreover, " $[t]$ he legal treatment of citizens by the State must be

5s See Mark F. Brzezinski \& Leszek Garlicki, Judicial Review in Past-Communist Poland: The Emergence of a Rechtsstaat?, 31 STAN. J. INT'L L. 13, 36 (1995) (quoting the Tribunal as stating that "nonretroactivity of law is one of the principles of a state based on rule of law'").

Id. at 42 .

iil Id. at 35 .

${ }^{61}$ ARNE MAVčič, SLOVEnLAN CONSTITUTIONAL, REVIEW: ITS POSITION IN THE WORID AND ITS ROLE IN THE TRANSITION TO A NEW DEMOCRATIC SOCIETY 108 (1995).

Id. at 109 . 
rational and foreseeable ... which is why restricting conditions should not be unclear and incomplete." ${ }^{, 3}$ The logic of the rule of law also "demands that statutory solutions be general and abstract." But here, too, rule-of-law principles are invoked precisely in moments when the Constitutional Court is about to say that a statute is unconstitutional.

In Hungary, as former Constitutional Court President László Sólyom wrote: "Of all constitutional principles, the rule of law played a special, symbolic role: it represented the essence of the system change, being the watershed between the nondemocratic, nonconstitutional, socialist system and the new constitutional democracy." The court promoted the apparently paradoxical idea of the "rule-of-law revolution," meaning that the revolutionary element of law in the new legal order would be precisely that law could not itself be changed in a revolutionary fashion. Legal continuity (state socialist era laws were presumed to be valid unless explicitly found to be unconstitutional) and legal security (law reform could not happen so quickly that it made it impossible for people to adjust in a reasonable manner) guided the transition in Hungary. ${ }^{67}$

The Hungarian constitutional principle of legal security animated all of its rule-of-law decisions. Having lived through the state socialist times, the justices of the Constitutional Court clearly believed that the regularity, predictability, and coherence of the law was far more than a formal guarantee; it was the hallmark element that indicated that the political realm had really changed. The new commitment to the rule of law gave substantive meaning to guarantees of rights and the separation of powers. Citizens had an affirmative constitutional protection not to be the subject of state experiments that operated through sudden changes of law. Instead, citizens had rights derived from the principle of legal security to have notice of changes in laws, to have time to adjust to new legal requirements, and not to be caught in the crossfire between changing or contradictory laws. And yet, the principle of legal security was typically used not to defend positive law, but instead to strike down statutes as unconstitutional.

"Id. at 137.

"I I . at 169.

"Lúszló Sólyom, Introduction to Derisions of the Constitutional Court of the Republic of Humgay, ir L íszló SólYoM \& GEORg BRLNNER, CONSTITUTIONAL JUdiciary IN A NEW DEMO'RiC:: The HuNg,tRLIN CONSTITUTIONAL COURT 1, 38 (1999).

"Ir.

1., Ih. at $38-40$. 
What is going on here? Have the new constitutional democracies gone constitution mad and forgotten the wise counsel that the law should be stable and certain, that judicial review should be used sparingly, that overconstitutionalization of law may be too much of a good thing? Constitutional courts in East-Central Europe have declared many statutes unconstitutional, and they have done much of this, perhaps even more bizarrely, in the name of the rule of law. To see what is going on here, it is worth noting just what sorts of laws are being struck down in the name of the rule of law, because the specifics tell a more compelling story than the general principles can.

In Poland, the Constitutional Tribunal used the rule-of-law clause in a set of pension reduction cases, saying that the law could not retroactively change pensions so as to require retirees to pay money back into the treasury but could be applied prospectively only. Even in prospective application, however, law could not affect rights that had already vested, since the maintenance of stable expectations was critical in a rule-of-law state. The new pension laws that radically revised the system as part of shock therapy were, therefore, struck down. $^{68}$ In Slovenia, the rule-of-law clause was extensively used precisely to police the constitutionality of the transitional laws that bridged the gap between one sort of regime and another. For example, the rule-of-law clause was used to strike down legislation that removed certain communist-era legal protections for those who lived in communes without substituting another stable legal framework under which commune dwellers' individual legal rights would be clear. ${ }^{69}$ The Slovenian Constitutional Court also, in the name of the rule of law, struck down a statute which picked out only certain specified plots of land and allowed them to be passed on to heirs through the new inheritance laws. Other equivalent plots of land were left out of this scheme because the privatization of land was incomplete, and therefore arbitrary distinctions had to be made if

Brzezinski \& Garlicki, supra note 58, at 36-37. In the case of ordinary citizens, the state was not allowed to change the formula by which pensions had been calculated, even if such formulas were changed by law. Those were rights that had vested because they were generally granted and had been relied upon-and therefore they could not be altered even by law. Id. at 39. Later the court was forced to relent, upholding cuts in welfare payments because of the dire economic state of the country which required "necessary departures from this principle." But the court retained the right to review the state budget to see whether in fact such welfare payments indeed had to be cut. Id. at 40 . It was clear, however, that the court tried constitutional remedies against statutory enactments to prevent the welfare of Polish citizens from succumbing to the personal shocks of shock therapy.

${ }^{69}$ MaVčič, supra note 61 , at 118-20. 
anything was to be done quickly. ${ }^{70}$ Similarly in Hungary, the Constitutional Court used the concept of the rule of law (or the entailed idea of legal security) to strike down attempts at retroactive criminalization of offenses that had been committed in the soviet era but that had not been prosecuted for political reasons. ${ }^{71}$ Later, the Hungarian Constitutional Court struck down parts of the IMFmandated austerity program that gutted welfare rights overnight, using the theory that people needed to be given time to adjust to the new economic order. ${ }^{22}$ The court often used the principle of legal security as a basis for preventing sudden legal changes from coming into effect. Sometimes the court also used the principle of legal security to engage in prospective overruling of statutes that were already in operation, declaring these laws to be unconstitutional but setting a time in the future when they would be nullified so that there would not be simply a destabilizing gap in the law caused by a decision of the court. ${ }^{7.3}$

The rule of law in postcommunist constitutional regimes has come to stand for a rejection of laws that rapidly unsettle expectations, push people into poverty by suddenly cutting their pensions or welfare benefits without giving them time to adjust, alter a formerly comprehensive legal scheme but only partially (so that certain people are left out arbitrarily), or attempt retroactive applications of the law. What all of these things share is what we might call law-abuse-they are changes that citizens may well consider abuse carried out under cover of law. What the state does in these cases has been done pursuant to a properly enacted law, but, simultaneously, the state has also pulled the rug out from under people who had long expected things to be different, or who had ordered their lives according to one set of state commitments, only to discover that they could not rely on the promises that were made. In

it Id. at 137-38.

71 Drision 11/1992: 5 March 1992, On Retroactive Criminal Legislation, translated in SÚlXOM \& BRUNNER, supra note 65, at 214-28; see also Gábor Halmai \& Kim Lane Scheppele, Living Well Is the Best Revenge: The Hungarian Approach to Judging the Past, in TRLísitional JUSTICE AND THE RULE OF LAW IN NEW DEMOCRACIES 155 (A James McAdams ed., 1997) (explaining that the Hungarians refused to go back and prosecute past crimes because they adopted the view that "the best way to deal with those who operated ouside the rule of law... is to refuse to follow the outlaw state's omm inner logic of arbitrariness and disregard for individual self-determination").

Th Drision 43/1995: 30 June 1995, On Social Security Benefits, translated in SólYoN \& BRUNNER, supra note 65 , at 322-32.

"I.́xsló Sólyom, Introduction to the Decisions of the Constitutional Court of the Republic of Hungany, in SólYOM \& BRUNNER, supra note 65, at $1,41$. 
transitional regimes, when a great deal of legal reform is being pushed through at once, it has been the rule-of-law principle that has prevented these legal changes from turning citizens into human subjects whose lives are radically worsened overnight by rapid and unsettling changes of the law. ${ }^{74}$ The rule of law has required that the effects of law on the subjects of the law be taken into account and moderated when such effects are harsh and sudden, when new laws change well-understood ground rules without notice, when new laws propose applying after the fact a law that wasn't in place at the time actions were committed, or when they put citizens in the crossfire of contradictory legal commands because the law reforms are partial and fail to comprehensively redefine a coherent legal world in which citizens can live. In short, the rule of law has been used often in postcommunist polities to strike down statutes (and not just the old soviet-era statutes). It has also come to stand for the proposition that the human subjects of law must themselves be taken into account in assessing whether law's effects are fair, reasonable, moderate, stable, and certain. The formerly formal rule-of-law virtues of predictability, certainty, and stability are still part of this new rule-of-law ideal, but they are far from merely formal guarantees. They are now guarantees that even the law will treat citizens with respect.

\section{The New Rule of Law}

This is just a small taste of comparative constitutional

${ }^{74}$ Some commentators have criticized this practice by calling the various constitutional courts that have acted in this way insufficiently postcommunist. For example, see András Sajó, How the Rule of Law Killed Hungarian Welfare Reform, E. EuR. CONST. REV., Winter 1996, at 31, 31 ("The social and political consequences of its 1995 social welfare decisions indicate that the rule of law and constitutional arrangements indeed play an obstructionist role, preventing changes to the inherited welfare system."). But when constitutional courts have done this, as in the cases mentioned above, they have not blocked the transitional laws altogether. Rather, they have slowed down the implementation of radical cuts in social rights, required safety nets when programs are abolished, ensured that all citizens be treated equally before new programs can be put in place, and generally ensured that the transition to a new form of economy and polity take into account the effects of these policies on those subject to them. While it is impossible to tell cause and effect here, it is notable that the relatively aggressive constitutional courts of Poland, Hungary, and Slovenia have been located in societies in which citizens have not felt the brunt of economic changes as severely as they have felt such changes in societies in which constitutional courts were not so active on these subjects (for example, Russia, Ukraine, Croatia, and Slovahia). The countries in which courts have aggressively intervened to protect people from economic experimentation are precisely the countries on the fast-track to European integration. 
jurisprudence on the rule of law. But despite the differences in constitutional traditions, contemporary constitutional texts, and concrete cases that have arisen before these various courts, there is clearly a core set of substantive principles for which the rule of law has come to stand in contemporary post-horror constitutional democracies. Unlike earlier formalistic rule-of-law conceptions, the modern conception introduces into constitutional jurisprudence the idea of the legal subject with legitimate expectations who is the real audience for the constitutional decision. Respecting such a legal subject is a high constitutional value. Respecting the legal subject requires that she be in the forefront of the judge's mind as the judge applies the law to her and it further requires that judicial elaboration of the law take into account its effects on those who based their goodfaith actions on the law that appeared to exist at the time their actions were taken. The legal subject, deserving respect, must have a sense that the law predates the actions that are judged under this law; ${ }^{75}$ that the law is capable of being understood and followed; that law does not require impossible or contradictory things; and that, if there is a gap in the law, it will be filled in using more general principles that are also knowable in advance. If the law is broken to the point where it cannot be fixed, a new set of legal principles cannot be retroactively put in place to require of the legal subject $20 / 20$ foresight.

One objection that can be made to this picture is that there is always more than one legal subject, and legal subjects may disagree. If it were so easy to work out one single clear set of expectations that legal subjects have, then judging would not be as complicated or conflictual as it is. The deep pluralism of most modern societies argues against the view that "the legal subject" is a meaningful unitary term for judges to use in determining what legitimate expectations are. What do constitutional courts, confronted with complicated societies full of disagreement over basic values and with diversity

This concern with the predictability of the law was echoed by Jeremy Bentham in his scathing critique of the common law method:

It is the judges ... that make the common law. Do you know how they make it? Just as a man makes laws for his dog. When your dog does anything you want to break him of, you wait till he does it, and then beat him for it. This is the way you make laws for your dog: and this is the way the judges make law for you and me. They won't tell a man beforehand what it is he should not dib-they won't so much as allow of his being told; they lie by till he has done something which they say he should not have done, and then they hang him for it.

JEREMN BENTHAM, 5 WORKS OF JEREMTY BENTHAM 233, 235 (John Bowring ed., Russell \& Rusuell, Inc. 1962) (1808). 
among legal subjects, do?

Disagreement cannot be wished away by theory. Nonetheless, disagreement may be better understood through a more specific analysis of context and through generating the kind of multiple and overlapping understandings of what conflictual events mean to those who are affected. This argues against a priori general resolutions of constitutional issues and counsels instead that the business of substituting constitutional principle for purely statutory resolution is one that requires both deep knowledge of the particular uses of the laws in question and clear justifications for declaring those laws to be unconstitutional by reference to the limiting facts of the particular circumstances.

For example, in the postcommunist pension cases, which have similar shape all over Eastern Europe, judges are not (as their critics claim) just developing a theory of positive rights with a nostalgic attitude toward communism and defying more liberal or libertarian senses of constitutionalism. Instead, judges are responding to a situation in which the present-day pensioners who bring these complaints had no choice through their lives but to live under a state policy that required everyone to depend on the state for their retirement income. The ability to save was limited in the soviet time; there were no other provisions for private creation of a retirement fund. Hyperinflation and bank collapses in the new market economies have often wiped out what savings people managed to amass. For people who were positively not allowed to plan for their old age, it seems particularly cruel for the state now to uphold the values of a market economy and the virtues of privatization when it is too late for pensioners to relive their lives to plan accordingly. The same rationale will not apply to generations that come later, generations that have had other options in life. So it is probably not accurate to say that the constitutional courts of Eastern Europe have a certain nostalgic fondness for social rights; instead, it is a specific sense of the rule of law that requires constitutional courts to validate the legitimate expectations of those who could do nothing else but depend on the state's promises to take care of them into their retirement years. Holding the functional disappearance of pensions to be unconstitutional relies on a specific analysis of a specific history in which the current complainants, through no fault of their own, are now desperate because of broken promises. This is not a view of the rule of law that blocks all future changes.

In the rule-of-law cases that I have just reviewed, a full-blown 
theory of general principles that indicate when the rule of law may be invoked in this substantive way may not be necessary. Constitutional courts in all of these cases are reviewing the constitutionality of laws in light of specific complaints brought against statutes in specific historical moments. The complaints highlight the effects of the statutes on the complainants, and it is through an assessment of the statutes' effects that judges determine whether further review is necessary. If the statutes have the effect of promoting not stability but ruin, not predictability but arbitrariness, not due notice but surprise, then the courts need to look further to see whether the laws in question produce these effects in ways that impinge on constitutionally guaranteed rights. The rule-of-law analysis is a way of pointing to how the complainant in a particular case has been treated by law and of asking whether the complainant has rights guaranteed elsewhere in the law that makes the complained-of treatment illegal or unconstitutional. If there are such rights, then the law itself may be unconstitutional in the name of the rule of law.

The rule of law does not and cannot guarantee the absolute predictability of concrete legal decisions in advance; such predictability would be either impossible or mechanical in ways that would be objectionable on other grounds. But it should at least make such decisions comprehensible when they are renderedcomprehensible as nonarbitrary, good-faith understandings of a stable order of law that takes note when citizens experience harm through law. But the rule of law, in its modern antiformalist version, requires that the subject of the law and not just the text of the law appear in the judge's field of vision. After the twentieth century's legal horrors, the new century's conception of a rule-of-law state is defined not by formalistic requirements but instead by a robust, substantive jurisprudence that takes the legal subject and her legitimate expectations seriously and does not use the legal subject as an opportunity for legal experimentation.

What could this new substantive rule-of-law jurisprudence in other countries possibly have to do with the painful election that America has just experienced? Surely, American courts are not bound by principles taken from other jurisdictions. And surely, America doesn't have the specific concrete history of engaging in mass abuse against its own citizens through law that seems to have led other countries to be suspicious of formalist understandings of the rule of 
law. ${ }^{76}$ But Election 2000 poses many of the problems that we see in newly emerging democracies committed to constitutionalism and the rule of law, starting with a flawed statute that had not been previously tested before its application mattered a lot, going through a series of court decisions that could not find a stable way to determine what to do with the law's flaws, and ending up with a whipsawing set of judgments that left everyone on both sides, ${ }^{77}$ even those who turned out to be the winners in the end, with a sense that the law itself had failed us badly. Through Election 2000, Americans had some glimpse of the "law abuse" that much of the rest of the world has long known.

Looking back over the fight after Election 2000, it is the fact that law couldn't explain the results of the most visible court decisions that has produced the sense that politics, and not law, was doing all of the work. But the Florida election law had real gaps and contradictions; courts differed in the clarity with which they acknowledged that fact and tried to find a principled way to solve the problem. Given the partisan nature of the dispute itself, it would have been hard for any court to find a strategy for judicial decisionmaking that would have been accepted as not directly partisan, given that any ground would have provided a particular outcome and the legitimacy of the ground for the decision would have been traced by the partisans to the

${ }^{76}$ Of course, there are those of us who believe that America has exactly this history, but this seems to be a minority view in the United States at the moment. It is difficult to square America's nonrandom pockets of extreme poverty, the continuing discrimination against already-disadvantaged groups, homelessness, lack of medical care, inadequate education, and a lack of opportunity for a large part of the American population with the rights allegedly guaranteed to all. But America's social problems have rarely been understood as a systemic horror, generated by the sort of regime we have. Instead, the causes of many of these social problems are privatized and are widely seen as the fault of the individuals affected. If these social problems were recognized as being the byproducts of the sort of political and economic system that we have and also as being the byproducts of the sort of legal protection that we offer people who are disadvantaged, America might have a very different understanding of the rule of law-to say nothing of a more humane society. But I will save that argument for another day.

${ }^{77}$ While I will concentrate primarily on the whipsawing that the U.S. Supreme Court engaged in here, $I$ understand that many people felt the same whipsawing, from the Florida Supreme Court in its efforts to find ways to count all of the ballots identified through Al Gore's selective requests and self-serving proposals. I believe that neither side was well served by law here, precisely because insufficient attention was given to these broader substantive rule-of-law issues. Had the Florida court jettisoned strict reliance on the gap-filled statute early on and substituted a "count every vote, but count every vote equally-across the whole state" standard, I suspect that even conservatives would have felt the result to be fair. Or at least it would have been harder to politicize the recount processes in the same way. 
desirability, from their perspective, of the outcome. But when we see the election wars waged with law as a weapon and the final result described frequently in the press as a Republican U.S. Supreme Court pulling rank on a Democratic Florida Supreme Court, the rule of law is the major loser. And with it, so are we all.

\section{THE TWISTED LEGAL LOGIC OF ELECTION $2000^{78}$}

The fateful and fatal legal problems of Election 2000 started with a flawed Florida statute that had been recently rewritten and never tested with all of its new provisions in place..$^{\gamma 9}$ And, unfortunately for all concerned, the statute was pressed to and beyond its limits. Florida's election law" was a detailed, apparently comprehensive statute that provided for many contingencies, but the various pieces were hard to reconcile and specific guidance was missing in critical places. The rule-of-law problems in Election 2000 did not grow primarily out of the facts of the election-though those facts launched legal challenges in the improbable situation of the complete political tie across almost all institutions of government. The rule-of-law problems grew instead primarily out of the flaws in the statute and the lack of agreement among courts over what to do with those flaws.

\section{A. Law's Flaws and the Protest Phase}

In Florida, the initial vote count on election night put Bush ahead of Gore by 1784 votes out of about 6 million votes cast. ${ }^{81}$ An automatic recount, triggered under Florida law because the gap between two candidates was less than one-half of one percent, ${ }^{8 z}$ took place over the

The account I give here only discusses those decisions that in some way were the preambles to the Supreme Court's final decision in Bush v. Gore, 121 S. Ct. 525 (2000) (per curiam). For a comprehensive list of all of the lawsuits, with original documents, see Robert Grown Law Library, Stanford Law School, Election 2000 Materials, at http://election2000.stanford.edu [hereinafter Election 2000 Materials]. For a more extensive treatment of all of the lawsuits, together with a discussion of the legal strategies insolved in arguing and judging them, see HowaRD GILLMAN, THE VOTES Thit Counted: The UNPRECEDENTED Judiclal Decisions That Decided The PRESIDENCX (forthcoming 2001).

The recent legislative modifications for the contest provisions of Florida's statute are detailed in Gor $x$. Hamis, 772 So. 2d 1243 (2000). Justice Harding's dissent in that case noted that in the protest part of the statute, the role of the circuit courts had been eliminated under the same revisions. Id. at 1270-71 (Harding, J., dissenting).

"'FL. STAT. ANN. \$\$ 97.011-107.11 (West 1982 \& West Supp. 2001)

"Eatuts Doy by Doy, P.ILM BEACH POST, Nov. 18, 2000, at 14A.

FLI.STIT. ANN. \$ 102.141(4). 
next week and set the difference between the two primary candidates at only 300 votes, with Bush barely hanging on to his lead. ${ }^{\mathrm{S} 3}$ After overseas absentee ballots were counted on November 20, Bush's advantage again grew, this time to 930 votes. $^{8 *}$ But all of the differences were vanishingly small in a state where 6 million ballots were cast and in a national election in which some 100 million people had voted. ${ }^{85}$ Due to the tiny margin between the two candidates' Florida vote totals, a series of legal challenges was mounted by the Gore legal team, by the Bush legal team, by various independent voters, as well as by voters affiliated with each camp. ${ }^{86}$ These lawsuits ran quickly into structural defects in Florida's election law.

Statutory Infelicity \#1. Florida Statutes Annotated section 102.111 specified that county voting returns must be submitted to the Florida Department of State seven days after the election or they "shall be ignored," under those circumstances. "Shall" implies no discretion; "may" implies some. This unfortunate drafting infelicity left open the question: Could (or must) the Secretary of State throw out results that came in after the deadline, according to the law?

Statutory Infelicity \#2. Section 102.166 provided a mechanism for protesting the election tallies at the county level and, under some circumstances, provided the option for a manual recount of disputed ballots. $^{89}$ But this section of the statute allowed candidates to challenge the count "prior to the time the canvassing board certifies the results for the office being protested or within 5 days after midnight of the date the election is held, whichever occurs later." The problem was timing. If a manual recount were requested just before the results had to be certified under the deadline set either by section 102.111 or by section 102.112 or if a recount were requested in a particularly large county in which manual recounts would take a

${ }^{83}$ Events Day by Day, supra note 81 . Between the initial count of a 1794 -rote gap and the 300-vote official gap after the automatic recount, Bush's lead steadily dropped and at one point was as low as 229 votes. Id.

*4 Todd S. Purdham \& David Firestone, Counting the Vote: The Florida Supreme Court, N.Y. TimeS, Nov. 20, 2000, at A1.

${ }^{85}$ Jonathan Ringel, The Election Litigation, by the Numbers, LEGAL TIMES, Dec. 11 , 2000 , at 17.

${ }^{86}$ For the detail on these other cases, see Election 2000 Materials, supra note 78.

${ }^{87}$ FLA. STAT. ANN. $\$ 102.111$ (West 1982 \& West Supp. 2001) (emphasis added).

Id. $\$ 102.112$ (West Supp. 2001) (emphasis added).

\&9. $I$. $\$ 102.166(4)(\mathrm{a})$.

90 Id. $\$ 102.166(2)$ (emphasis added). 
substantial amount of time, then there would be no time to complete the recount that the law clearly seemed to allow. If the county performed the recount, it would miss the deadline. That drafting infelicity left open the question: Did the deadline bend for the manual recounts, or did the manual recounts bend for the deadline? The statute itself didn't explicitly say.

Statutory Infelicity \#3. The Florida election law is a unitary statute, meaning that there is, in general, one set of procedures to govern all types of elections in the state, even though the elections are very different." The same protest procedures are outlined for elections for county sheriff, for governor, for U.S. Congress, and for presidential electors. But some of those elections are county-based, others are statewide; some are to state offices, others are to federal posts. The protest procedure for all of these offices, however, requires that candidates challenge the vote tallies before the relevant county canvassing board. ${ }^{92}$ Even in a statewide election, there is no procedure for protesting a statewide vote tally unless one files separately in every county in the state. And the instructions about how to respond to the protest petitions from candidates are directed at county canvassing boards, which are to look only to their own county results in figuring out whether such a protest is warranted. ${ }^{93}$ That left open the question: When should (or how could) one file a statewide protest? And, since a protest in a statewide election must be

"There is one important difference at the "contest" level, where a candidate may challenge the certification of election results. Elections to the Florida Senate and House of Representatives are contested before those bodies themselves, while all other contests go to the courts. Id. $\$ 102.171$.

" 2 This can be seen in id. $\$ 102.166(4)$ (a), which provides, "[a]ny candidate whose name appears on the ballot... may file a written request with the county canvassing board for a manual recount."

Section 102.166(4)(d) further indicates that the county board may' authorize a sample recount, implying that there is discretion lodged in the board to accept or reject the request. But the statute gives no standards for the boards' determinations, leaving open the very real possibility that, even if a candidate challenged a statewide clection by filing in every county, different boards would reach different conclusions about whether the tallies had to be revisited. This was of particular consequence with regard to the statutory provision invoked by the Gore team, which allowed the cansassing boards to authorize full manual recounts if the sample manual recount "indicates an error in the rote tabulation which could affect the outcome of the election." Id. \$102.166(5). If the gap between Gore and Bush had been wider, it might have been possible for each county canvassing board, looking at its own county's results, to say that a recount of its county, by itself, would not have affected the ulection. If each one did that, then no one would have recounted even if the rote totals, when added up across all of the affected counties, would have been sufficient to change the outcome of the election. But this question did not arise this time. 
mounted by filing at the county level, how could one guarantee that the same standards were used by each county in considering this challenge across the state?

\section{B. Playing Out the Protest Phase}

The day after the election, the Gore team decided to challenge the election returns only in four counties-Volusia, Broward, MiamiDade, and Palm Beach-selected because they had large numbers of Democratic voters and also because there were indications that a substantial number of ballots had been rejected by the machines there as having no vote for president. ${ }^{95}$ If one were trawling for Democratic

${ }^{94}$ At oral argument before the Florida Supreme Court at the protest phase, David Boies noted that his client had offered to go along with a statewide recount:

Vice-President Gore informally, obviously, he didn't have the power that this court has, but informally proposed, as the court may or may not be aware, that he would be prepared to accept a statewide recount. We are not urging that upon the court. But certainly that is something that we have indicated that we would accept. And we believe the court has the power to order that.

CNN LIVE EVENT: The Florida Recount: Florida Supreme Court Holds Hearing on Manual Recounts (CNN television broadcast, Nov. 20, 2000) (Transcript \#00112005V54). At the contest phase, the Gore team clearly felt that its best strategy was to contest specific votes in specific counties rather than ask for a statewide recount. David Boies explained:

This is not a situation in which somebody has simply come in and said we've lost, we'd like to have a recount under the contest statute. This is a situation in which we have identified specific votes, many of which were agreed by the District Court were votes in which you could clearly discern the voter's intent. Contesting the Vote: Arguments Before the Florida Supreme Court on the Presidential Recount, N.Y. TIMES, Dec. 8. 2000, at A34. But Florida Supreme Court Justice Peggy Quince at oral argument at the contest phase questioned the linkage between contest and protest, and asked whether the two phases had to have the same general shape. "[Y]ou contested these ballots through the original protest. So do you have to have done that in order to bring a contest?" Id. Boies's response was that the Gore team was contesting those same uncounted ballots in the same counties where the protests had been lodged but, literally speaking, there was nothing in the statute that required that contests be limited to counties where unsuccessful protests had already been made. As if to help the Gore side, Justice Barbara Pariente asked Boies whether there had ever been a statewide recount sought as a remedy in an election contest, and Boies replied that there had been such a contest in 1916 but not "in the modern era." Id. So while the statewide recount option was always on the table, it was also always pushed aside in favor of what a more literal reading of the statute seemed to urge.

${ }^{95}$ The vigorous dissent by Judge Carnes in Siegel w. LePore, 234 F.3d 1163 (11th Cir. 2000) (en banc), challenged the argument that the reason for selecting the particular counties for a recount was based on the view that every vote should count. Analyzing the counties where the most undervotes were missed did not turn up the same list of counties that the Gore team challenged. "Never once in its briefs or in its oral arguments did the [Democratic] Party suggest that its selection of the 3 punch card counties out of 24 for a manual recount was based on anything other than partisan 
votes, then, this was where they would most likely be. The Gore team strictly followed the procedure that the statute laid out, because challenges had to be filed at the county level and there was, as we have seen, no provision either requiring or even providing for a general statewide challenge in a statewide race. Not that the Democrats necessarily preferred a statewide challenge; the county-level challenge seemed, at the start, to promise them the best results. But the statute did not push them in that direction either; Gore's challenge was squarely within the legal framework that the Florida Legislature set out, though it was questioned by the Bush team precisely because it was selective. The Republicans continually challenged whether protesting only in a few counties made sense as a method of questioning a statewide election, although they showed no signs of remedying the situation by filing for recounts in all of the counties where Gore had not already filed. And because the Florida courts felt that they had to work with what the statute literally said, Florida's judges did not (at least at first) believe that they could force such a procedure on the litigants in the protest phase, although the subject had come up in the first set of oral arguments. ${ }^{96}$ The Republicans, too, were no doubt acting strategically, especially as it emerged in the news that the highest rates of rejected ballots where a manual recount would find additional votes were in counties using punch-card technologies, and those counties were likely to be disproportionately Democratic."

Following the Gore team's initial request, each of the targeted counties took at least a one percent sample of the ballots in at least three precincts, as Florida law provides, to determine whether the manually recounted sample might be sufficiently different from the

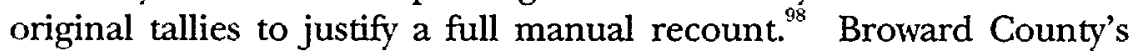
sample turned up a net four votes for Gore;" Palm Beach's sample

self-interest." Id. at 1205.

"'st Supra note 94 (providing statements of the Florida Supreme Court Justices from oral argument). After the contest was over, Florida Supreme Court Justice Pariente noted poignantly that the absence of a statewide contest provision was one of the many features that should be remedied in the Florida election law. But she noted, too, that the option had been raised in oral argument on November 20, 2000, in Gore v. Hamis, 773 So. 2d 532-33 \& n.18 (Fla. 2000).

"Josh Barbanel \& Ford Fessenden, Contesting the Vote: The Tools; Racial Pattern in Demographics of Error-Prone Ballots, N.Y. TIMES, Nov. 29, 2000, at A25.

FLA. STAT. ANN. \$ 102.166(4)(d) (West Supp. 2001).

"H Broward's manual recount eventually turned up a net 567 votes for Gore. Legal Disputes ozer Florida's Electoral Votes: Key Events, FACTS ON FILE WORLD NEurs DIGEST, Dec. 13, 2000, at $964 \mathrm{AI}$, LEXIS, Nexis Library, UPI File. 
netted Gore nineteen votes. ${ }^{100}$ These counties went ahead and started manual counts because they felt this showed an adequately significant difference, given the closeness of the election, to warrant it. Volusia plunged straight into a full recount and, in the end, finished in time to satisfy the original statutory deadline, though it was not at all sure, even on the day the counts were due, that it would be able to meet the deadline. Miami-Dade's canvassing board took a sample and said the differences it found were not substantial enough to warrant recounting the whole county. But the board reconsidered later, started a recount, then decided again against the recount, and eventually just stopped. ${ }^{101}$ In all the counties, recount processes were more difficult and took longer than expected because of the large number of partisan challenges and the extraordinary flood of lawsuits against the canvassing boards. In addition, the county canvassing boards were caught in the crossfire because they were getting conflicting legal advice from the state about what they were supposed to do. ${ }^{102}$

Throughout, the Bush campaign took the view that manual recounts were likely to introduce inaccuracies rather than correct them and argued that allowing "selective" manual recounts in only some counties and not in others was unfair, biasing the process in favor of the Democrats. ${ }^{103}$ So the Bush campaign attempted to block the manual recounts on this basis by going to federal court with an

${ }^{100}$ Palm Beach County Canvassing Bd. v. Harris, 772 So. 2d 1220, 1225 (Fla. 2000). In the end, Palm Beach found 188 net additional votes for Gore after its full recount. Legal Disputes over Florida's Electoral Votes, supra note 99.

inl Legal Disputes over Florida's Electoral Votes, supra note 99. Later vote counts showed Miami-Dade would not have made much difference to the election. The Palm Beach Post count showed Bush netting six votes over Gore in Miami-Dade County, while the Miami Herald count said Gore netted forty-nine votes over Bush. Bob Drogin, Recounts in Miami-Dade Find Bush a Fair Winner, L.A. TIMES, Feb. 27, 2001, at A10.

${ }^{102}$ Emergency Petition for Extraordinary Writ (Expedited Consideration Sought), filed by Palm Beach County Canvassing Board, Palm Beach County Canvassing Bd., No. 00-2346 (Fla. Nov. 14, 2000), at 2-3, available at http://election2000.stanford.edu/ harrisflscpet.pdf ("Petitioner is uncertain about its rights, responsibilities and duties under Florida law."). The petition also noted that there were seven lawsuits pending against board members in either their official or personal capacities at the time that they filed this petition. Id. at 3 n.1.

1is Bush's chief spokesman in Tallahassee, James Baker, said as the recounts started: "There are not even any procedures or standards to govern ... [a] selective vote count. A manual recount permits the electoral boards in each county in Florida to determine the intent of the voter without setting forth any standards at all for deciding that intent." Baker Calls for "No Further Recounts, "N.Y. TIMES, Now. 12, 2000. at A24. 
equal protection claim, asking for an emergency injunction. The district court rebuffed them, ${ }^{1 / 4}$ and ultimately the Eleventh Circuit, in an en banc decision, rejected the argument as well. ${ }^{105}$

But while the federal case was working its way through the courts, Florida's Republican Secretary of State Katherine Harris, who had served as George W. Bush's campaign co-chair in the general election, issued an opinion in response to a request from the Palm Beach County Canvassing Board for clarification of the manual recount standard, stating that manual recounts should only be performed when there was a problem of fraud or machine breakdown, not simply a predictable error rate in the tabulation equipment. ${ }^{106}$ Florida's Democratic Attorney General Bob Butterworth, who had been Al Gore's campaign co-chair, issued, unbidden, a contrary view, ${ }^{1107}$ and so the Palm Beach board stopped counting and turned to the Florida courts for a definitive reading of what standards they were to use in authorizing a manual recount. Ultimately the Florida Supreme Court told them that nothing barred their continued counting, and the Palm Beach board resumed counting after a delay. ${ }^{101}$

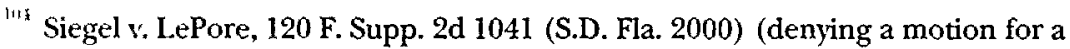
temporary restraining order and injunction). The Bush campaign put forward a number of Florida voters as the primary plaintiffs here given that, as they noted in their filing. if an equal protection right exists, it is a right of the voter and not of the candidate. The emergency motion for a temporary restraining order and preliminary injunction was filed on November 11,2000 . But the federal district court refused relief.

Siegel v. LePore, 234 F.3d 1163 (11th Cir. 2000) (en banc). The original Palm Beach County case had been joined with a case coming from Volusia County which produced separate dissents, Touchston v. McDermott, 234 F.3d 1133 (11th Cir. 2000). The majority rejected the equal protection argument as being insufficient to justify the remedy sought, to the effect that " $[n]$ o authority from the Supreme Court or the Elerenth Circuit has been cited to us for the proposition that the irreparable injury needed for a preliminary injunction can properly be presumed from a substantially likely equal protection violation." Siegeh, 234 F.3d at 1177-78 (quoting N.E. Fla. Chapter of the Ass'n of Gen. Contractors of Am. v. City of Jacksonville, 896 F.2d 1283, 1285 (11th Cir. 1990)). But Judge Carnes's dissent argued that there was a potential equal protection violation in the unequal error rates of different voting technologies uned in different counties.

"St" Se Legal Opinion From Florida Secretary of State To Assist Palm Beach County Regarding the Recount Deadline, DE 00-13 (Nov. 13, 2000), available at http:/ / election2000.stanford.edu/secstatel 114pbc.html.

Manual Recount of Ballots, No. AGO 2000-65 (Nov. 14, 2000), available at http://clection2000.stanford.edu/agopinion11_14.html.

[I]t appears that the relief sought on the question of whether the Canvassing Board may conduct a manual recount of the votes cast for President and Vice President has been answered in the affirmative by the Circuit Courts of Leon and Palm Beach County. At present, this is binding 
In the meantime, the clock was still ticking. By the time the Palm Beach County Canvassing Board resumed their count, the statutory one-week deadline for submission of election returns was upon them. The Palm Beach County Canvassing Board, along with the canvassing boards of Broward and Volusia counties, petitioned the Secretary of State for an assurance that their manually recounted returns would be accepted after the deadline. But they were told by the Secretary that the seven-day deadline was firm and that nothing coming in after that deadline would be counted in the certified totals. ${ }^{109}$

That generated another lawsuit-this time in Leon County Circuit Court (seat of the state government)-in which the canvassing boards, joined by Al Gore, tried to force the Secretary of State to accept late returns. Judge Terry Lewis noted the conflict between the "may ignore" and "shall ignore" provisions of the Florida law and decided that, in light of the manual recount petitions, "may" had to triumph over "shall." "It is unlikely," wrote Judge Lewis, "that the Legislature would give the right to protest returns, but make it meaningless because it could not be acted upon in time."110 As a result, Judge Lewis ruled that the Secretary in fact had discretion to accept late returns but, further, that discretion meant that she could not reject late returns automatically in advance. To exercise discretion properly, she had to consider "all of the facts and circumstances" that accounted for the delays." "May" it was, then. Judge Lewis specifically noted that the statute provided a "contest" option for challenging results after they had been certified and that one way to challenge the results was to point to the "rejection of a number of legal votes sufficient to change or place in doubt the result of the election." "112 Judge Lewis's opinion strongly suggested, then, that if the Secretary still chose to ignore results submitted after the deadline, Gore could contest the certification and get the "legal votes" added to

legal authority on this issue and there is no legal impediment to the recounts continuing. Thus, Petitioners are authorized to proceed with the manual recount.

Palm Beach County Canvassing Bd. v. Harris, No. 00-2346 (Fla. Nov. 16, 2000) (order allowing recounts to continue), available at http://election2000.stanford.edu/002346order1116.pdf.

${ }^{109}$ Secretary of State Harris's opinion regarding the finality of the election deadlines can be found at http://election2000.stanford.edu/fll 1-14deadline.pdf.

${ }^{110}$ McDermott v. Harris, No. 00-2700, slip op. at 4-5 (Fla. Cir. Ct. Nov. 14, 2000) (granting in part and denying in part a motion for a temporary injunction), available at http://election2000.stanford.edu/McDermottHarris.pdf.

III Id. at 7 .

${ }^{112} I d$. at 8 (quoting FLA. STAT. ANN. $\S 102.168(3)$ (c) (West Supp. 2001)). 
the totals later. One way or another, under Judge Lewis's judgment, the results of the manual recount would be added to the certified vote totals."

Secretary Harris then told the canvassing boards that they needed to explain, in advance of their submission of late returns, why they needed an extension of the deadline before she would consider including the returns if they came in late. The canvassing boards submitted their reasons and, within hours, Secretary Harris rejected all of them for failing to state an acceptable ground for missing the deadline. ${ }^{114}$ Judge Lewis signed off on this by saying that Harris had done what he had asked in demonstrating an exercise of discretion considering all of the facts and circumstances and that "[m]y Order requires nothing more." ${ }^{\mathrm{H} 5}$

Quickly, the canvassing boards and the Gore team appealed Judge Lewis's ruling using a special "pass through" procedure to skip the intermediate appeals court review. The Florida Supreme Court immediately issued a stay against the Secretary of State, telling her that she could not certify the election, as she had planned, until it considered the claims." Then the Florida Supreme Court ordered the case to be briefed, heard oral arguments, and issued a unanimous

11: From a more positivist stance than the one I am urging in this essay, Judge Lerwis's opinion was the most perceptive of all of the Florida court opinions because it recognized that results of a legitimately conducted manual recount would have to be added to the totals-if not, because of deadlines at the certification phase, by the Secretary of State, then at least at the contest phase through court challenge. Also, by noting that the Secretary of State had discretion, rather than a statutory mandate, to reject late returns, Judge Lewis squarely placed responsibility on the shoulders of an elected official charged with carrying out the law, who then had to justify her actions in public view as elected officials should have to do when charged with major public responsibility. Judge Lewis's opinion cleanly separated the operation of law (in the contest phase) from the exercise of political discretion (in the protest phase) and did so without doing something obviously activist (or capable of a partisan reading), such as changing the statutory deadlines or requiring a political official charged with discretion to do something she didn't want to do. In the political swirl of the time, neither side was pleased with Judge Lewis's result, and any judgment promising a consequential result would have been challenged to the bitter end. But Judge Lewis might hate had the winning framework that kept courts most separate from partisan politics in those bitter days, without going beyond the statute.

11 Defendant's Memorandum in Opposition to Motion for Temporary Restraining Order and Preliminary Injunction at 3-4, McDermott v. Harris, No. 002700, available at http:/ / election2000.stanford.edu/dmemo2700.pdf.

11. McDermott v. Harris, slip. op. at 2 (denying emergency motion to compel compliance with, and for enforcement of, injunction).

"." Palm Beach County Canvassing Bd. v. Harris, No. SC00-2346 (Fla. Nov. 17, 2(110) (staying order), available at http://election2000.stanford.edu/stay.pdf. 
per curiam judgment on November 21, 2000. In its decision, the court ordered the Secretary to delay certification until November 26 , giving the county canvassing boards additional time to finish their recounts. ${ }^{117}$

The Florida Supreme Court's per curiam opinion grappled with Statutory Infelicities \#1 and \#2 in the Florida law and decided, much as Judge Lewis had, that the "may" language won over the "shall" language precisely because the manual recount provision would be meaningless if it were a remedy that a candidate could never use because a requirement that the deadlines be met was unresponsive to special circumstances. But the Florida Supreme Court went further and found that, while the Secretary had discretion to determine what to do with late tallies in general, she had no discretion to refuse to accept late tallies under these circumstances. The rationale? Legislative intent clearly planned for manual recounts to be a real remedy to correct mistakes in the vote tallies, and, therefore, the legislature could not have required or even permitted the Secretary to ignore the results from lawful manual recounts. Thus, while the Secretary could reject late returns for some reasons, she could not reject late returns for this reason. The court's analysis was bolstered by its view that the Florida Constitution, in its Declaration of Rights, placed the right to vote high in its ordering of constitutional values, and so anything that ensured that Florida citizens' votes would be given fuller effect took precedence over rigid statutory deadlines. ${ }^{118}$

The Florida Supreme Court's previous order allowing manual recounts remained in place, so Broward County, at least, had continued to count. Volusia had finished its recount in time for the original deadline, so its recount results were poised to be certified in the results whenever such certification was made. Palm Beach had again stopped counting, losing valuable time (at least as far as the Gore forces were concerned) while awaiting legal guidance from the Florida Supreme Court. They began again only after the court came down with this decision. Miami-Dade, which at first had decided against a manual recount and then changed its mind, started up again too. But Miami-Dade stopped when unruly protesters filled the building where the counting was being done. While the Miami-Dade board said that they stopped the counting because they thought that

\footnotetext{
117 Palm Beach County Canvassing Bd. v. Harris, 772 So. 2d 1220 (Fla. 2000).

${ }^{11}$ See id. at 1237 ("Technical statutory requirements must not be exalted over the substance of this right.").
} 
they could not get it done in time even under the extended deadline, Democrats believed that it was local political officials and the protestors who pushed the vacillating board out of the fray. ${ }^{119}$

Outraged by the deadline extension which they felt had judicially altered the legislative scheme and therefore changed the law after the election, the Bush team petitioned for review by the U.S. Supreme Court, and, surprisingly to many commentators, ${ }^{12 / 1}$ the U.S. Supreme Court granted certiorari on the petition from the Florida Supreme Court. $^{\text {i.l }}$ The Supreme Court's grant of certiorari didn't change things on the ground, for the manual recounts continued in Florida while the U.S. Supreme Court was awaiting briefs, hearing oral argument, and preparing its decision. By the time the U.S. Supreme Court's decision came down on December $4,{ }^{122}$ it seemed grandly irrelevant. The Florida Secretary of State had certified the results on November 26, including the manual recounts from Volusia and Broward counties. Since Palm Beach County had not met this deadline, its additional votes from a partial recount had been ignored. And since Miami-Dade had decided to stop recounting altogether, no new figures were available there either. With all of the jockeying for advantage in the manual recount battle, Bush had retained his lead even after the certification deadline had been pushed back by twelve days, and he didn't seem to need the U.S. Supreme Court to rule for him in the precertification recount battles anymore. Florida's

11." Later, a story was published in the New York Times purporting to show that there were a number of local political reasons why the nominally Democratic elected officials in Miami may not want have wanted to alienate the Republicans on this matter. Don Van Natta Jr. \& Dexter Filkins, Miami Mayor's Role a Riddle in Decision to Halt Recount, N.Y. TIMIE, Dec. 1, 2000, at A1. Apparently, the protestors had been mobilized by the Republican organization in Miami-Dade to disrupt the recount process. Dana Canedy \& Dexter Filkins, A Wild Day in Miami, with an End to Recounting, and Democrats' Going to Cout, N.Y. TMES, Nov. 23, 2000, at A31.

1.'" Prior to the U.S. Supreme Court's decision to hear the case, experts were nearly unanimous in saying that the Supreme Court would never get into this because it was clearly a matter of interpretation of state law, raising no substantial federal questions. Sex, e.g., CNN Early Edition: The Florida Recount: State Election Law vs. Coustitutional Questians (CNN television broadcast, Nov. 17, 2000) (Transcript \#00111709V08).

${ }_{121}$ The Bush team had appealed both the Palm Beach County Canvassing Board case from the Florida Supreme Court, in Palm Beach County Canvassing Bd. v. Harris, 772 So. 2d 1220 (Fla. 2000), and also the denial of an injunction in Siegel r. LePore, 120 F. Supp. 2d 1041 (S.D. Fla. 2000). But the Supreme Court denied certiorari in the Siegel case, in which Bush had presented his equal protection argument in fullest form. See Siegel v. LePore, 121 S. Ct. 510 (2000).

1:2 Bush v. Palm Beach County Canvassing Bd., 121 S. Ct. 471 (2000). 
certified totals put Bush's lead at 537 votes. ${ }^{123}$ If the certification had proceeded on the Secretary of State's calendar, his lead would have been 930 votes, making him the narrow winner in either event.

The Supreme Court's decision and reasoning added to this sense of relative insignificance at the time. The per curiam unanimous opinion vacated, but did not reverse, the Florida Supreme Court's decision and asked the Florida Supreme Court only to clarify the basis of its decision. Following up on a series of questions asked by Justice Scalia at oral argument, ${ }^{124}$ the per curiam opinion noted that, while in general the Court gives great deference to state court interpretations of state law, this case involved substantial federal questions as well, particularly those arising under Article II, Section 1, clause 2 of the United States Constitution, which gives the power to determine the manner of choosing presidential electors to the state legislature ${ }^{12,3}$ and 3 U.S.C. $\S 5$, which, in the view of the Court, "would counsel against any construction of the Election Code that Congress might deem to be a change in the law." ${ }^{126}$ The Court expressed concern that the Florida Supreme Court might have relied on the state constitution to constrain the power of the legislature to determine the manner of choosing presidential electors, which the Court implied might be prohibited by the federal Constitution. ${ }^{127}$ Therefore, strict construction of the election statute without recourse to general state constitutional principles seemed wisest course of action for the Florida Supreme Court.

But given that the Florida election had been certified and Bush was still the winner, the specific legal ground of the Florida Supreme Court's first major opinion seemed like a question of interest only to the technically minded because it was not relevant to the political outcome. It plainly allowed the Florida Supreme Court to go back and reach the same result as long as it clarified that its reasoning was

${ }^{123}$ Ringel, supra note 85.

${ }^{124}$ Oral Argument, Bush v. Palm Beach County Canvassing Bd., $121 \mathrm{~S}$. Ct. 471 (2000) (No. 00-836), 2000 WL 1763666, at *66*68. Justice Scalia asked Gore counsel Laurence Tribe to indicate what in the record showed that the Florida Legislature "affirmatively invited the Florida Supreme Court" to enter election litigation and to "interpose" the Florida Constitution. These questions paved the way for the view expressed in the per curiam opinion that the proper way to conceive of the law in this area was as a constitutional delegation to the state legislature to pass a law with quasifederal status, practically immune from state court construction in light of state constitutional law. Id.

${ }^{125}$ See Palm Beach County Canvassing Bd., 121 S. Ct. at 473-74 (per curiam).

${ }^{126} I d$. at 474 .

127 Id. at 475. 
based firmly on the intent of the Florida Legislature and careful readings of the narrowly relevant federal law. And it seemed clearly to direct the Florida Supreme Court not to go beyond the statute to the Florida Constitution in working out what remedies might be granted. In the results-driven atmosphere of the election challenges, the U.S. Supreme Court's first decision in the election battle apparently changed very little-it was more like a technical whimper than a substantive bang.

\section{Law's Flaws and the Contest Phase}

The Gore team, however, was determined to press its challenge to the vote tallies, and to do so on the basis of their original theory. They' believed that legal votes had been excluded because the machines had failed to count the "undervotes," ballots that the machine had registered as blank that a human eye might register as a vote. The manual recounts had not been completed in Palm Beach or Miami-Dade Counties in time to have the result added in to the certified vote totals. So the Gore team filed a suit under the "contest" provisions of the Florida law, alleging that "legal votes" had been rejected from Palm Beach and Miami-Dade Counties and urging their inclusion in the certified totals. ${ }^{128}$ But the Gore team quickly learned that there was a new set of statutory infelicities awaiting their challenge under the contest provisions.

Statutory Infelicity \#4. In the "contest" phase under Florida election law, a candidate who still believes that there are serious flaws in the election tallies may challenge the certification of the election results. ${ }^{12 \prime \prime}$ Unlike in the protest phase when the complaint goes to the

1.4 Complaint to Contest Election at 19-22, Gore v. Harris, No. 00-2808 (Fla. Cir. Ct. Nov. 27, 2000), available at http://election2000.stanford.edu/CV-00-2808a.pdf. Specifically, the Gore team asked (1) that the 215 net votes for Gore that the Palm Beach County Canvassing Board had identified but which came in too late for the Secretary of State to count be added; (2) that the 3300 votes in Palm Beach County that Democratic abservers had determined were votes for Gore but which the County Canvassing Buard had not certified be further counted for Gore; (3) that the 168 net votes for Gore identified in the partial recount in Miami-Dade county be added to the totals, even though the whole county had not been recounted; (4) that Miami-Dade be urdered to recount manually approximately 9000 "undervotes;" and (5) that the 51 net votes for Bush that had been added by Nassau County be excluded since they reflected the first election night totals rather than the required automatic recount totals that the county had previously submitted.

1." The relevant law then shifted from FLA. STAT. ANN. $\$ 102.166$ to FLA. STAT. ANN. $\$ 102.168$. Under the Florida law as it stood before 1999, there was not a sharp split between protest and contest phases. All challenges were taken up from the first 
county canvassing boards for their resolution, the contest phase sends all complaints directly to the Florida courts, which are given very broad latitude to investigate and fashion remedies to fix any complaints they find to be valid. ${ }^{130}$ But this great judicial power does not come with many critical constraints-the most crucial one in the presidential electors context being whether there are any deadlines in the process. The deadlines loom large for presidential electors because these elections have a unique set of time constraints coming from federal law that Florida law does not seem to have built into the statutory provisions about contests. ${ }^{131}$ According to federal law, presidential electors are generally immune from later challenge in the Congress when they have been duly selected pursuant to a procedure put in place before the election and when they themselves are in place six days before they have to cast their electoral votes. ${ }^{132}$ Further, they are supposed to meet to cast their ballots on the "first Monday after the second Wednesday in December," was December 18. But the contest provisions of Florida law recognize no such explicit deadlines by which the electors must be chosen. That leaves the following questions: What happens to the remedies normally available in a contest period if the contest happens to occur in races for presidential electors? Do candidates simply have fewer remedies when time is short, or are there expedited procedures available in such cases? Can expedited procedures cut certain corners in order to obey the calendar? If so, which corners can they cut? Or

moment by courts. Under the revisions of 1999, the election challenges were split into two phases, where the first phase was to be handled by county canvassing boards and the second phase was to go to the courts for most elections, including the election of presidential electors.

130 "The circuit judge to whom the contest is presented may fashion such orders as he or she deems necessary to ensure that each allegation in the complaint is investigated, examined, or checked, to prevent or correct any alleged wrong, and to provide any relief appropriate under such circumstances." FLA. STAT. ANN. $\$ 102.168(8)$ (West Supp. 2001).

${ }^{131}$ Florida law does recognize some special rules for presidential electors, see id. $\$ \$ 103.011-.71$ (West $1982 \&$ West Supp. 2001), but these are rules about how electors are selected for the ballot and how missing electors shall be replaced, how write-in candidates for president can be recognized, and such. There is no attempt to reconcile the provisions for presidential electors in Chapter 103 with the protest and contest provisions for challenging vote counts in Chapter 102.

${ }_{132} 3$ U.S.C. $\$ 5$ (1994).

${ }^{133} I d . \$ 7$ (1994). Florida law recognizes this in FLA. STAT. ANN. $\$ 103.051$ (West 1982) ("The presidential electors shall, at noon on the day which is directed by Congress, meet at Tallahassee and perform the duties required of them by the Constitution and laws of the United States."). 
can state law remedies affect the federal deadlines in the way that they have already affected the state deadlines? Which federal deadlines are crucial for state law?

Statutory Infelicity \#5. If a judge decides that a contest identifies a legitimate problem, then under section 102.168(8) of the Florida Statutes Annotated, the judge can "provide any relief appropriate under such circumstances." There is no further guidance to the judge. So, how is a judge to proceed if she believes that a violation of election law has occurred? If, for example, some votes haven't been counted, shall they be counted? All of them? Only where they were challenged, or across the state? By whom and with what standards? Or if, for example, some votes have been counted, but inconsistently under the decisions of the canvassing boards in the protest phase, what then? Or if some "legal votes" have been located, but the canvass within a county wasn't finished? Or if there is good reason to believe that the same problems occurred in other counties where a recount did not occur, then what? And what is a "legal vote" anyway? statute provides no standards, no answers, no guidance. It is, in short, hard to construe strictly.

\section{Playing Out the Contest Phase}

The first problem that the Gore team encountered in the contest phase was the messy problem of facts. Judicial remedies take time, in no small part because judges must have facts, and facts require trials. Though an evidentiary hearing was expedited, it didn't take place until December 2-3, 2000. The hearing was short because the Gore team truncated its testimony to just two witnesses in order to speed the process along, and the Bush team, while clearly ready to go on a great deal longer, was pushed by Leon County Circuit Judge N. Sanders Sauls to limit itself to just a handful of witnesses. If the case really rested heavily on its facts, then the Democratic plaintiffs were in trouble because they simply didn't present much of the evidence that would have allowed them to win on the facts. But the Gore team obviously decided that their strong suit was legal interpretation rather than factual proof, so a complete trial was one of the corners that they were willing to cut. In the end, however, Judge Sauls's opinion went

FLA. STAT, AN. \$ 102.168(8) (West Supp. 2001).

$\therefore$ The Florida statute allows a challenge on the basis of "rejection of a number of legal rotes sufficient to change or place in doubt the result of the election." Id. $\$ 102.168(3)(c)$. But the statute does not define "legal vote." 
against the Gore team on every particular, finding that the proof it presented did not meet its legal burden, and so the court would not even proceed to the validity of its legal arguments about how the statute ought to be interpreted. Not a single one of its arguments met with success. ${ }^{136}$

The Gore team appealed again on an expedited basis to the Florida Supreme Court, which on December 8, 2000 came down with a four-to-three judgment that went largely for Gore. ${ }^{137}$ The majority per curiam opinion agreed that the additional net votes for Gore from the complete recount results in Palm Beach County and the additional net votes for Gore that resulted from the partial recount in Miami-Dade County should both be added to the state certification, since they were legal votes that had been excluded from the certification. $^{138}$ Most significantly, however, the Florida Supreme Court's majority thought legal votes might well be found in any of the undercounted votes across the state, not just in the places that the Gore team had hand-picked. The majority wrote:

[I] $t$ is absolutely essential in this proceeding and to any final decision, that a manual recount be conducted for all legal votes in this State, not only in Miami-Dade County, but in all Florida counties where there was an undervote, and, hence a concern that not every citizen's vote was counted. ${ }^{139}$

The court ordered a statewide manual recount but, though the Gore team had asked repeatedly for a more definite standard to be used in counting the votes as this manual counting continued, ${ }^{14 \prime \prime}$ the

${ }^{136}$ Gore v. Harris, No. 00-2808 (Fla. Cir. Ct. Dec. 4, 2000), available at http://election2000.stanford.edu/CV-00-2808-10.pdf; see also Transcript of Judge Sauls's Order, Gore v. Harris, available at http://election2000.stanford.edu/002431_transcript.pdf.

${ }^{137}$ Gore v. Harris, 772 So. 2d 1243 (Fla. 2000) (per curiam).

${ }^{138}$ Id. at 1248 .

$139 \mathrm{Id}$. at 1253 .

${ }^{140}$ Brief for Appellants, or in the Alternative, Petition for Writ of Mandamus or Other Writs at 32-34, Gore v. Harris (No. SC00-2431), available at http:// election2000.stanford.edu/00-243liniGore.pdf. The Gore team also emphasized this point in oral argument. Before the Florida Supreme Court on November 20, 2000, David Boies urged, "this court needs to act expeditiously to set the standard." Asked where the standard would be found, Boies said, "I think you find it partly in Florida law, but I think you can also find it from the laws of other states that have dealt with these very same questions .... I think it is important to the integrity of the process. I think if you had very wide variations you could raise constitutional problems." CNN Live Event: The Florida Recount: Florida Supreme Court Holds Hearing on Manual Recounts, (CNN television broadcast, Nov. 20, 2000) (Transcript \#00112005V54), available at LEXIS, News Library, Transcripts. In oral argument before the U.S. Supreme Court 
Florida Supreme Court hesitated in saying anything more specific than to repeat the very general words of Florida's Legislature that "no vote shall be ignored 'if there is a clear indication of the intent of the voter' on the ballot, unless it is 'impossible to determine the elector's choice." "1

Among the three dissenters on the seven-member court, Chief Justice Wells opposed the majority view most strongly. He said that the majority should have deferred to the trial judge here, since he at least had a defensible view of the pre-existing law, while the majority's view was novel. ${ }^{1 \pm 2}$ Chief Justice Wells argued that undertaking a statewide recount of the undervotes neglected the potential legal votes that could be found in those ballots that had two candidates marked for president (the "overvotes") ${ }^{143}$ and also that the court failed to establish uniform procedure and standards that would allow all legal votes to be equally recognized. ${ }^{1 * 4}$ In obvious frustration with the situation, Chief Justice Wells noted that the various questions posed by the 2000 presidential election in the State of Florida could not be solved "with an election code which any objective, frank analysis must conclude never contemplated this circumstance." ${ }^{45}$ But Chief Justice Wells, together with Justices Harding and Shaw, who dissented separately, all concluded that, whatever the right answer was under Florida law, it was too late to find it out with the care that the process deserved. The December 12 "safe harbor" date for having electors in place in order to insulate them from congressional challenges was fast upon everyone by the time this case was decided on December 8 . In the conclusion to his dissenting opinion which argued that there was a wrong but no remedy because of the looming deadlines, Justice Harding quoted football coach Vince Lombardi as saying, "We didn't lose the game, we just ran out of time."146

The contest period, now seen as radically shortened by the Florida

on December 11, David Boies argued, "I think there must be a uniform standard. I think there is a uniform standard. The question is whether that standard is too general or not. The standard is whether the intent of the voter is reflected by the ballot." CNN Live Event: U.S. Sufreme Court Hears Arguments in Bush Challenge of Florida Rermint (CNN television broadcast, Dec. 11, 2000) (Transcript \#00121101V00).

${ }^{111}$ Gore v. Harris, 772 So. 2d at 1254 (quoting FLA. STAT. ANN. $\$ 101.5614(5)-(6)$ (W'est Supp. 2001)).

II' Id. at 1264 (Wells, C.J., dissenting).

11. Id. at $1264 \mathrm{n} .26$ (Wells, C.J., dissenting).

"Id at 1269 (Wells, C.J., dissenting).

IV. Id. at 1269-70 (Wells, C.J., dissenting).

11" Id. at 1273 (Harding. J., dissenting). 
Supreme Court's first decision extending the certification deadline, had already nearly run the clock. But in a burst of energy under the direction of Leon County Circuit Judge Terry Lewis, the manual recounts started statewide that evening, with the idea that they would all be finished by Sunday, December 10, leaving time for legal challenges to be made before the December 12 "safe harbor" date. But corners had to be cut. After a few tries at getting a fast but fair procedure in place by going back to the county canvassing boards and whatever warm bodies they could find to do the counts, Judge Lewis changed the plan. He ultimately decided that county-level judges statewide would be responsible for the count and would in fact do it themselves, allowing no time for individual challenges to particular ballots until the count was done. And although it would have surely been helpful to have a more specific standard, especially for the punch-card ballots where there had already been much conflict over how many perforated corners the "chad" had to dislodge before the ballot could count as a vote, the "intent of the voter" standard mentioned in the statute was given as the only guidance to the counters. This failure to provide a more specific standard was in all probability a result of the Florida Supreme Court's reluctance to go beyond the literal words of the Florida election law after what they had just been instructed to do by the U.S. Supreme Court. At this point, the primary goal was the most accuracy that could be mustered consistent with the speed necessary to get the count done, and all within the four corners of the statute under the most conservative interpretation of the requisite timeline.

On December 9, upon urgent petition from the Bush team seeking to halt the statewide manual recount, the Supreme Court responded with an unusual stay order. Not only was the stay granted, and the Florida Supreme Court's order on manual recounts suspended, but the stay application was treated as a petition for a writ of certiorari which the Supreme Court immediately granted, with briefs to be filed the next day and oral argument to be heard the day after that. Moreover, this was a stay decision with opinions. Justice Stevens, along with Justices Souter, Ginsburg, and Breyer, dissented publicly from granting the stay on the grounds that no irreparable harm to the petitioner had been demonstrated from allowing the count to continue. ${ }^{147}$ But Justice Scalia, concurring in the stay, noted that the order "suggests that a majority of the Court ... believe that 
the petitioner has a substantial probability of success" ${ }^{148}$ and that the stay' was necessary because the continued count would "threaten irreparable harm to petitioner, and to the country, by casting a cloud upon what he [the petitioner] claims to be the legitimacy of his election." "1"

In Florida, the vote count halted. The Florida Legislature, pursuing another strategy, continued its special session, determined to vote its own slate of electors for George W. Bush to cover itself in the event that the courts pushed the election into the Gore column. ${ }^{150}$ Briefs for the Supreme Court were written in great haste, without much response time for the briefs to focus clearly on making and rebutting arguments on the same points. Oral argument occurred on the morning of December 11 when the ink was barely dry on the briefs. And then there was what seemed like a long silence as the U.S. Supreme Court worked out what to do. ${ }^{151}$

A bitterly divided Supreme Court issued its final five-to-four judgment in the matter at $10 \mathrm{p} . \mathrm{m}$. on the evening of December 12, the day on which Florida's electors would have to be certified in order to achieve immunity from challenge when the electors presented their votes to the Congress. A per curiam opinion called a halt to the election but did not say so in so many words. Instead, the opinion announced a series of conclusions that, taken together, were quite surprising: (1) "The individual citizen has no federal constitutional right to vote for electors for President of the United States unless and until the state legislature chooses a statewide election as the means to

IT. Id. (Scalia, J., concurring).

"Id. (Scalia, J., concurring).

1" David Firestone, Cantesting the Vote: The Overview; With Court Set To Hear Appeal, L. givlators Mon't on Electors, N.X. TIAIES, Dec. 7, 2000, at AI; see Jo Becker \& Thomas B. Eduall, Legislatur Rtady To Support Bush, WASH. POST, Dec. 9, 2000, at A1. In the interest of full disclosure, I should mention that I was called as one of the "conutitutional experts" to testify before a committee of the Florida House of Rtpresentatives on behalf of the Democratic position that it was premature at best to declare that the election had produced no victor under 3 U.S.C. $\$ 2$. Also, I argued that Article II, Section I, clause 4 of the U.S. Constitution required that all electors be choven on the same day, which a legislative appointment subsequent to election day would violate.

ii) The silence was only long given the specific context. Ordinarily, of course, the Supreme Court does not issue opinions the day after oral argument. But everyone here knew the clock was ticking and, in particular, knew that the safe harbor date of December 12 was, if not a hard deadline, at least a significant point of no return. As the clock ran almost to the end of the safe harbor period, a tense national media kept watch outside the Court and gave minute-by-minute reports on when the decision would come down. 
implement its power to appoint members of the Electoral College." (2) Such a right, if granted by the state legislature, is fundamental, unless the legislature decides to take it back, which it can do at any time, ${ }^{153}$ making this a highly unusual fundamental right. (3) The right to vote for electors, if granted by a state legislature, rises to an important enough level to require the application of equal protection standards. $^{154}$ (4) The Florida Supreme Court's order of a statewide manual recount of undervotes failed the Fourteenth Amendment equal protection test because it did not include the recount of overvotes, set up a specific standard for determining intent in undervoted punch ballots, specify who should do the recounts, provide a timely manner for objecting to decisions made while the recount was going on, or in general provide assurance that "rudimentary requirements of equal treatment and fundamental fairness are satisfied." 155 To fix this problem, the per curiam opinion stated:

[I] $t$ is obvious that the recount cannot be conducted in compliance with the requirements of equal protection and due process without substantial additional work. It would require not only the adoption (after opportunity for argument) of adequate statewide standards for determining what is a legal vote, and practicable procedures to implement them, but also orderly judicial review of any disputed matters that might arise.... Use of the equipment [to screen out undervotes or overvotes so that they might be separately counted] ... and any new software developed for it, would have to be evaluated for accuracy by the Secretary of State....

And, according to the U.S. Supreme Court's majority, the Supreme Court of Florida had said that the legislature intended to have the electors in place by December $12 .{ }^{157}$ Since that day had

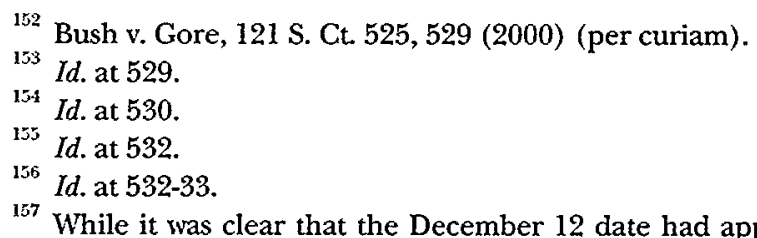
discussions of deadlines from the time of the first protest actic had accepted that the December 12 date was significant, the Florida Supreme Court had never literally said that it felt bound by a legislative wish to meet the deadline, and the statute made no specific attempt to reconcile the contest provisions with the deadlines for selecting presidential electors. Perhaps the strongest evidence of "legislative wish" in the record before the Supreme Court at the time they decided Bush $v$. Gore was the amicus brief filed on behalf of the Florida Legislature by Harvard Law professors Charles Fried and Einer Elhauge and attorney Roger Magnuson. This brief asserted that the present legislature did in fact wish that the election contest be 
arrived and since the onerous requirements needed to ensure a fair recount could not possibly be met in the two hours left before the deadline elapsed, any recount would, of necessity, be unconstitutional. $^{15}$ The U.S. Supreme Court reversed the Florida Supreme Court and remanded the case, but of course there was nothing left for the Florida Supreme Court to do within the deadline that the U.S. Supreme Court insisted was the one that the Florida Legislature wanted.

Over four vigorous dissents, the Supreme Court's bare majority called a halt to the election. Gore's challenge had run out of time because a recount could not be conducted under the sort of uniform standards that the Court, for the first time on December 12, had announced. The Florida statute itself didn't anticipate these issuesthat there would be a need for statewide challenges and statewide standards that would meet federal equal protection requirements. The Florida statute also said nothing about a legislative preference to settle electors by December 12; it took no note of the special timing for selecting presidential electors at all in settling contests. For the U.S. Supreme Court decision to be followed, there would have to be a

brought to a close in order for the state to take advantage of the safe harbor provisions. Set Brief of the Florida House of Representatives and Florida Senate as Amici Curiae in Support of Neither Party and Seeking Reversal at 18, Bush v. Gore, 121 S. C. 525 (2000) (No. SC00-949), available at http://election2000.stanford.edu/ floridahousel.pdf ("[T]he Florida Supreme Court majority opinion would vitiate Florida's safe harbor under 3 U.S.C. $\$ 5$ because it requires a manual recount that cannot be fairly completed and finally adjudicated before midnight December 11 [sic]. This not only deviates from the Florida Legislature's wishes, but from the Florida Supreme Court's own prior opinion, which stated that manual recounts should not be counted if they would be 'submitted so late that their inclusion will [. . .] preclude Florida's voters from participating fully in the federal electoral process." (quoting Palm Beach County Canvassing Bd. v. Harris, 772 So. 2d 1220, 1239 (Fla. 2000))). At least some justices of the Florida Supreme Court did not believe that they had committed their court to that date, nor had the Florida statute. Justice Shaw, concurring in the Florida Supreme Court's decision wrapping up the election cases, noted "[I]n my opinion, December 12 was not a 'drop-dead' date under Florida law. In fact, I question whether any date prior to January 6 is a drop-dead date under the Florida election scheme." Gore v. Harris, 770 So. 2d 524, 529 (Fla. 2000) (Shaw, J., concurring). Justice Pariente, quoting Justice Ginsburg's dissent noting that the December 12 date lacked the significance that the Supreme Court in Bush v. Gore had assigned to it, commented that " $[t]$ he time limits Congress enacted for resolving contests in Presidential elections were established in a far different time," and suggested that "perhaps the time has come for Congress to explore whether, in the rare case of a post-election presidential controversy, a thirty-five day time limit for a final resolution of a presidential contest is realistic or reasonable." Id. at 530 (Pariente, J., concurring.)

Bush v. Gore, 121 S. Ct. at 528. 
definition of a legal vote, and agreements about how to interpret undervotes and overvotes, none of which the statute defined with any precision. If new standards for Election 2000 were developed after opportunity for argument, as the Supreme Court suggested, then the creation of such standards would itself void the protections provided by 3 U.S.C. $\$ 5$ because a state may not take advantage of the safe harbor if its law has been changed since election day.

That leaves us with the simple question at the end of it all: What was the election law in Florida that applied to the 2000 election? Or, for that matter, what was the operative law in the election nationwide through which George W. Bush became President of the United States? In a rule-of-law state, we should be able to tell. But can we?

\section{RULE-OF-LAW ISSUES IN THE FLORIDA ELECTION}

The U.S. Supreme Court majority in the story of the 2000 election seems to have taken its inspiration from the Knights Who Say NI! in the Monty Python version of the Arthurian legend. Dressed in dark uniforms and towering above the petitioners who came before them, the Justices of the Supreme Court possessed the magic words that, when shouted in chorus, caused those who needed their permission to proceed to cower before them. For it was by pronouncing the magic words that the Supreme Court Justices could cause the most selfconfident pretender to the throne to slink away. And, as in the standard fairytale, the Court could set a challenge for the pretender to the throne who, if he met the challenge, must be allowed to get what he sought. The majority's reading of the fairytale requirements, however, follows Pythonesque conventions rather than the standard ones, and it deviates substantially from what the emerging comparative constitutional standard for rule of law would require.

Between Bush v. Palm Beach County Canvassing Baard (the protest phase case) and Bush v. Gore (the contest phase case), the Supreme Court turned itself from the Knights Who Say NI! into the Knights Who Go Neeeow ... wum ... ping!, no longer "contractually bound" to be satisfied by a litigant who met the challenges that were set originally and who was therefore looking to pass. Transforming itself into the Knights Who Go Neeeow ... wum ... ping!, the Supreme Court had other ideas. In its new guise, instead of being satisfied by a shrubbery brought before it designed according to their initial request (a solution crafted under a literal reading of the Florida statute), the majority insisted on a new shrubbery with a totally different design (federal constitutional equal protection analysis 
rather than the literal wording of the Florida statute set the standard). New magic words were necessary to pass through this part of the dark forest of the law, except that the Knights had obviously tired of the game and so simply declared it over.

What is wrong with this, on a rule-of-law account? A great deal, but let me concentrate on two things in particular:

(1) The Whipsawing Problem: There was an apparent shift in the legal frameworks that were found to be important as one case followed another, leading to a sense that the applicable law was not stable and making it very difficult for anyone to orient their conduct in light of the law either before, during, or after the sequence of litigation.

(2) The Impossibility Problem: There was, in the per curiam opinion in Bush $v$. Gore, an announcement of two crucial legal conclusions-that an equal protection test applied to court-ordered vote-counting procedures and that 3 U.S.C. $\$ 5$ combined with a "legislative wish" required that recounts not be extended past the December 12 "safe harbor" date. But these two conclusions worked at cross-purposes. Meeting one required violating the other, and vice versa. With this logic, there was simply no place left to stand to claim a remedy that the law seemed to allow and perhaps even to require. The election was declared over as it stood at the moment the Court issued its decision, and no state has ascertained whether the results as they stood on the evening of December 12, 2000 met the equal protection standards the court laid down.

From all of this, we might legitimately wonder whether the United States in fact decided its most recent presidential election according to any coherent law at all.

\section{A. The Whipsawing Problem}

It is an often-praised feature of American courts that they operate in an incremental and partial way, that they take matters on a case-bycase basis, that they consider only arguments put forward by the parties, and that they decide issues only insofar as they have to, limited by the facts of each case. ${ }^{159}$ Law stays in its modest and limited place by virtue of the fact that judges are supposed to be humble about their ambitions to set the world to rights in their decisions. The

rat, rg., CASS SUNSTEIN, ONE CASE AT A TME (1999) (identifying and defending "minimalism" as a distinctive form of judicial decisionmaking). 
incremental common law brings together ideas over time into the seamless web of the law, so the story goes, and the coherence of law is ensured by the fact that in its many tiny stitches, American law produces a needlepoint of order. Of course, we can all think of areas of law in which, over time, many small decisions led over time to very substantial changes. Common law systems are not static, and the accretion of small adjustments (punctuated by some fewer, larger ones) creates a law that is flexible and adaptable to changing times. Or at least those features that lead to incremental yet significant change are portrayed as the great strengths of the common law. ${ }^{\text {th }}$

But there are occasions when American incrementalism makes a hash of the rule of law, and Election 2000 was one of those times. There were so many different lawsuits, raising very similar problems in quite different ways, that the American court system was overwhelmed. Dozens, perhaps hundreds, of lawyers wrote briefs to deal with the narrowly drawn legal issues before them in each particular challenge at each particular phase of the process (as they are, in a common law system, supposed to do), and courts wrote decisions similarly, dealing at a minimum with what they had to, leaving to the future any question they could. The problem was that the future was the next day, or the day after that, and so the press of cases that might have caused the law to change gradually over time in the usual common law manner caused the election law of Florida to change from day to day in a way that tossed the candidates and their supporters up and down from elation to depression, from legal victory to legal defeat.

All of these incrementalist decisions taken together produced an incoherent patchwork of successful arguments, and yet what was at stake was a single election whose outcome needed to be known and needed to be understood as the application of a single set of rules. Some general principles were needed to resolve like cases alike (and even to determine which cases were alike) because the cases were going to be decided close enough to each other in time that they needed to be imagined together and because they were going to be aggregated into a single result for the same election. The problem was aggravated by the drafting problems in the Florida statute, so courts had to try to announce the governing principles as they went along and as one new statutory infelicity was discovered after another. The time pressures, the extremely high stakes, and the extraordinary

${ }^{16}$ I would like to thank Seth Kreimer for focusing my attention on the way in which traditional methods of common law judging are implicated in this set of problems. 
number of cases brought to challenge various parts of Florida's election framework put extraordinary pressure on incrementalism. As a result, instead of seeing the often-touted virtues of the case method, what we saw instead was whipsawing.

In Bush v. Palm Beach County Canvassing Board, the U.S. Supreme Court's per curiam opinion laid out a framework that the Florida Supreme Court was to follow in thinking about the presidential elector cases in general, and presumably not just in the one before it in the protest phase. As the per curiam decision emphasized, the U.S. Constitution in Article II, Section 1, clause 2 gave the power to determine the manner of choosing electors to the state legislature. The state legislature's word was, therefore, to be given special deference in the matter. The U.S. Supreme Court left the strong hint that the Florida Supreme Court should not rely on its own state constitution or any judicial creativity to help it sort out what the state election statute meant. To be safe from further reversals, the Florida Supreme Court could have reasonably thought that strict and literal interpretation of the Florida law was required since the federal constitutional procedures for choosing presidential electors built in a special role for the state legislature, whose views of the matter must therefore take precedence. The Supreme Court seemed to say that the only constraints that could be imposed on the state legislature also had to come from federal law, and it chose to highlight Congress's role in setting the timing for selecting electors. ${ }^{161}$ The U.S. Supreme Court seemed to warn the Florida Supreme Court that if it went too far in constructing the law through interpreting the statute creatively, then this might by itself pose constitutional problems because the lawnaking power in this area was clearly given to the state legislature without necessarily presupposing any role for state courts.

In that first decision, the U.S. Supreme Court did not mention any other constitutional requirements that would further constrain interpretation of this law. But the equal protection theory had been put on the table in the federal litigation that George W. Bush had already brought (and lost) in federal court. Bush had sought review by the Supreme Court of his consistent defeats on this issue in federal court at the same time that he sought review of the Florida Supreme Court's protest phase decision. But according to long-standing convention and our incremental practices, we were not supposed to be able to conclude anything from the Supreme Court's denial of

${ }^{11,1}$ U.S, CONST. art. II, $\$ 1$, cl. 4. 
certiorari in the federal case or from the refusal of the Supreme Court to entertain a question that had not been fully addressed below. Still, in the heated context of the election challenges, the denial of certiorari on the equal protection claim and the limitation of questions to the Article II and 3 U.S.C. $\$ 5$ points seemed to imply that there was no substantial equal protection claim to be argued. If time was of the essence here (and of course, the U.S. Supreme Court's later decision in Bush v. Gore indicated that time was the only essence), then why put off that question unless it wasn't part of resolving Election 2000? Of course, the Court put it off because it wasn't part of the incremental challenge before it from the Florida Supreme Court's protest phase case.

The case that came back to the U.S. Supreme Court in the contest phase had different parties ${ }^{162}$ and was brought under a different part of Florida law. ${ }^{163}$ But it involved the same set of demands in the same ongoing dispute, and one would expect that it would be decided according to the same basic set of constitutional principles already identified as central for choosing presidential electors. Gore still wanted a manual recount that would find legal votes among the Florida undervotes in particular and Bush didn't want the recount to occur. The relevant law had been staked out as the Florida election law (taken in isolation from other Florida law), the U.S. Constitution's Article II, Section 1 provision for selecting presidential electors, and its associated federal law. ${ }^{164}$ In the second round of challenges under the contest phase of the Florida statute, Gore had, as he had in the first round, followed what the statute appeared literally to require: $\mathrm{He}$ had filed in the appropriate state court a legal challenge setting out the specific ballots that he wanted to challenge (even the U.S. Supreme Court did not question that). ${ }^{165}$ And the Florida Supreme

${ }^{162}$ It was now Gore directly whom Bush sought to halt, not the county canvassing boards whom Gore had called into service. Throughout the Election 2000 litigation, it was often unclear whether the correct parties were before the court. Were the candidates or the voters or perhaps even the electors the proper plaintiffs? W'ere the county canvassing boards the proper defendants throughout? This awaits closer procedural analysis. I am grateful to Ed Hartnett for exploring these issues with me.

${ }^{163}$ Bush v. Gore was about a challenge under section 102.168 of Florida election law, whereas Bush v. Palm Beach County Canvassing Board featured a challenge under section 102.166.

${ }^{164} 3$ U.S.C. $\$ \$ 1-15$ (2000).

${ }^{165}$ As David Boies pointed out in oral argument before the Florida Supreme Court, previous Florida cases had allowed a few specific ballots to be challenged in particular elections and did not seem to require that all of the votes from a whole precinct, district or state be counted. "This is a situation in which we have identified 
Court on appeal had settled on a form of remedy that was hard to challenge, since the statute plainly gave the court broad equitable powers to fix any wrong they found. But the second time Al Gore returned to the Supreme Court, the Knights Who Formerly Said "NI!" (where "NI!" highlighted the literal meaning of the statute and deference to the legislature, which has constitutionally granted power in the matter of presidential electors) now said "Neeeow ... wum ... ping!" (where the new magic words signified that equal protection and fundamental fairness were the crucial constitutional guiding principles, even if that meant literally ignoring the state statute to which the Florida Supreme Court had been previously instructed to accord such special deference).

Perhaps the Supreme Court was right about the standards the second time around. Perhaps the right to vote for presidential electors does need more constitutional protection to ensure the fundamental fairness of the counting procedures and the equality of treatment of all of the votes. Those seem like quite sensible principles for running federal elections. In the abstract, by my lights at least, they are far more sensible than the decentralized and arbitrarily unequal procedures we now have in place, even though the current decentralized structure of federal elections was clearly an intentional part of the original constitutional design. ${ }^{166}$ But if that was going to be the most important rule that all had to play by, why did the Supreme Court not say so in its first opinion on the matter, when the State of Florida had already clearly launched into a set of recounts that allowed different standards to be used in different counties? If $\mathrm{Al}$ Gore had wanted to play by the rules to see whether he in fact got more votes in the State of Florida than George W. Bush, he would, at a minimum, need to know what rules he was playing by.

The rules that were determined to be the operative rules in play by the end of the process were not announced in advance. Instead, the U.S. Supreme Court's first opportunity to lay out an election framework in Bush v. Palm Beach County Canvassing Board resulted in a decision that made it affirmatively more difficult for the Florida Supreme Court to guess at what the right rules would eventually be deemed to be. The Florida Supreme Court, in its November 21

specific votes." Arguments Before the Florida Supreme Court on the Presidential Recount, N.Y. TINIES, Dec. 8, 2000, at A34 (quoting David Boies).

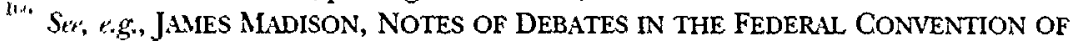
1787, at 401-05 (W.W. Norton \& Co. 1987) (1840); see also U.S. CONST., art. II, \$ 1, cl. 2 (setting forth the provisions regarding the selection of presidential electors). 
decision in Palm Beach County Canvassing Board v. Harris, had laid out one workable method of statutory construction, using garden variety methods of statutory construction along with the Florida Constitution to figure out a way to cope with the gaps and contradictions in state law. But the U.S. Supreme Court apparently thought that the Florida Supreme Court had insufficiently recognized the federal constitutional and statutory issues here and suggested that the Florida court rethink its reasoning, keeping these suggestions in mind.

Had the Florida Supreme Court understood that they should apply federal constitutional equal protection or due process principles in order to fill in the missing spaces in the defective Florida statute, they probably would have eagerly complied. Since the Florida statute gave the court broad powers to fashion remedies in the contest phase, the Florida justices could have worked out a way within Florida's existing election law to count the ballots with uniform statewide standards derived from a Fourteenth Amendment analysis. ${ }^{167}$

But the U.S. Supreme Court's first decision positively disabled the Florida Supreme Court from figuring out what the U.S. Supreme Court would deem to be the right solution in the end. By appearing to elevate the state election statute to quasi-federal status-since the state legislature had been given an extraordinary power by the U.S. Constitution in this one matter-the U.S. Supreme Court gave a warning to the Florida Supreme Court that it would not look kindly on attempts to improvise more detailed requirements than the state statute already provided. So, the Florida Supreme Court reasonably took its task to be giving meaning, so far as possible, to the flawed statute itself, not reading in more precise standards to be used in the vote counting that the legislature had not already and literally put there. The Florida Supreme Court therefore declined to give further specification to the "intent of the voter" standard or to set out a standardized procedure for ensuring that different county counters used similar objective tests. Given the U.S. Supreme Court's decision in Palm Beach County Canvassing Board, filling in the blanks in Florida's gap-filled election law with constitutional principles seemed to be

${ }^{167}$ The three dissenters from the Florida Supreme Court's majority opinion in the contest action did note that there were problems with the absence of standards and procedures in the recount, in addition to noting that time was too short to conduct the recounts. But, as former dissenter Shaw said in his concurring opinion in the December 22, 2000 judgment bringing the case to a final halt, he had dissented only from the standardless recounts, not from the general view that all votes should be counted, even if it took longer than the December 12 date. 
courting a reversal.

So it was a particularly cruel blow when the U.S. Supreme Court's per curiam opinion in Bush v. Gare arguably implied that the Florida statute was itself unconstitutionally vague because it failed to recognize and detail methods for providing "at least some assurance that the rudimentary requirements of equal protection and fundamental fairness are satisfied." Justice Pariente's wistful yet defiant concurrence suggested in the final Florida Supreme Court decision wrapping up the election:

[T] he United States Supreme Court's decision in Bush v. Gore has also called into question the constitutionality of any statutory scheme that does not have more specific standards for evaluating votes when conducting manual recounts than the one currently codified by Florida law, which is whether the intent of the voter can be ascertained. However, before the 2000 presidential election, neither the Legislature nor the Secretary of State had prescribed more explicit criteria to govern the determination of the voter's intent. ${ }^{169}$

As Pariente further noted, "Neither candidate raised the constitutionality of Florida's election laws as an issue on appeal to this Court. Instead, President Elect Bush chose to bring a separate challenge to the constitutionality of section 102.166 in federal court [where it was rejected]." 17 "

Since neither of the parties, nor the U.S. Supreme Court itself when it remanded Bush v. Palm Beach County Canvassing Board to the Florida Supreme Court, put the federal constitutional equal protection or due process claims squarely before the Florida Supreme Court, the court could be forgiven for not considering a challenge not raised under the usual American rules about incrementalism. Bush had raised these questions in the federal courts while seeking an injunction to halt the manual recounts, but neither the federal district judge nor the Eleventh Circuit thought that there was merit in his

Bush v. Gore, I21 S. C. 525 (2000) (per curiam). There is some ambiguity about how to read the opinion here. In its narrow reading, it seems to claim that equal protection problems only arise when a court-ordered statewide recount is at issue. But it is not clear how that would be distinguished on principle from the broader reading-that equal protection issues arise whenever vote counting is done within a state without a common set of standards to be used county to county and even counting team to counting team.

Al." Gore v. Harris, 773 So. 2d 524, 534 (2000) (Pariente, J., concurring) (citation and footnote omitted).

1'1" Id. at 524, n.25 (citation omitted). 
argument ${ }^{171}$ and the Supreme Court, when initially asked to review the equal protection and due process arguments, denied certiorari to hear the appeal even as it granted certiorari to hear an appeal from the Florida Supreme Court case in Palm Beach County Canvassing Board $v$. Harris. ${ }^{172}$ It certainly seemed reasonable for the Florida Supreme Court to believe that federal equal protection principles were not even on the table as they considered this case and, given what else the Supreme Court said, the justices of the Florida Supreme Court might well have thought that it would be inadvisable to invoke a federal equal protection or due process rationale to decide the next case that came before them in the contest phase if they wanted to avoid reversal.

If Bush v. Palm Beach County Canvassing Board and Bush v. Gore had been separated by a few elections and not just by a few days, then the move from one to the other might be more comprehensible in the common-law scheme of things. As times change, Article II problems can change into Fourteenth Amendment issues with new facts and new sensibilities and due time to argue the matter. If several elections had separated the two decisions, then new sets of litigants would have had a chance to adjust to the first theory of elections; they would have had a chance to critique this theory and come up with new arguments to which their opponents, and a new court, could respond. But because the two cases were separated by less than two weeks and the theory of how to read an election statute with flaws was changed so radically in so little time, the litigants (and the voters) could be forgiven for feeling that the law had been pulled out from underneath them.

It is this sort of "law abuse" that various post-horror constitutional courts would recognize immediately as something that they themselves should not do. Post-horror constitutional courts consider that litigants and the broader audiences for court decisions should not feel as though they are the subjects of legal experimentation, even if it is possible that a theory of legal interpretation would give

${ }^{171}$ Siegel v. LePore, 120 F. Supp. 2d 1041 (S.D. Fla.) (denying a request for a preliminary injunction to stop the recount), affd, 234 F.3d 1163 (11th Cir.) (en banc), cert. denied, 121 S. Ct. $510(2000)$.

${ }^{172}$ On November 24, 2000, the U.S. Supreme Court simultaneously granted certiorari in Bush v. Palm Beach County Canvassing Board, 121 S. Ct. 471 (2000), and refused certiorari in Siegel v. LePore, 121 S. Ct. 510 (2000). Although Bush also made the equal protection and due process arguments in the petition for certiorari in Palm Beach County, the Court did not engage those either, perhaps because those arguments had not been presented fully below to the Florida Supreme Court. 
alternative readings equal plausibility de novo. Having chosen onethe Article II reading - the Court should have given up the possibility of changing its mind so quickly to the Fourteenth Amendment theory, not because the Fourteenth Amendment arguments are substantively implausible, but because giving them conclusive weight at such a late stage of the proceedings seemed even more than usual to be changing the rules after the fact. ${ }^{123}$ Alternatively, it would have been far better for the Court to have dealt with both the Article II and the Fourteenth Amendment issues at once when it had the chance in Palm Beach County Canvassing Board, in order to give both Bush and Gore a reasonable opportunity to try to work out their challenges under a stable understanding of the relationship between federal constitutional and state statutory election law.

The speed-up of constitutional evolution that occurred in the election cases reveals a weakness in the American legal system. While there is always a danger in the common law incrementalist method that particular litigants will be unsettled, the danger increases a great deal when events are changing so fast that a court is tempted to update its view of the matter before the parties to a case have had a

1:. The common law violation here may be that the Court came up with two different legal frameworks for analyzing the same set of facts. But a purist might note that the protest and contest cases were not exactly the same. In the protest case, the question before the U.S. Supreme Court was whether the Florida Supreme Court had impermissibly changed the election law or merely interpreted it. For that, Article II provided a reading of what the Florida Supreme Court's responsibility was in the area of presidential electors. By the time the case came back in the protest phase, the U.S. Supreme Court was faced with a court-ordered statewide recount under standards that were very general. The per curiam opinion tried to tailor a ruling to apply only to the ituation of a statewide manual recount ordered by a court. But the problem of tandards in counting the vote had been there from the start, and the U.S. Supreme Court's late adherence to an equal protection theory therefore appears to be merely outcome-oriented. For this reason, the Rehnquist concurrence in Bush v. Gore offends less against rule-of-law principles because it does carry through the implications of the Article II reasoning that was at the heart of Bush v. Palm Beach County Canvassing Board. Bush v. Gore, 121 S. Ct. 525, 533 (2000) (Rehnquist, C.J., concurring). The per curiam decision does not exen mention the Article II argument, perhaps because there was another difference in the two cases. The protest phase case was raised under a part of the statute that saw the county canvassing boards as the main bodies that could provide remedies while the contest phase explicitly lodged broad powers in courts to remedy any alleged wrong. Under those circumstances, where the statute explicitly gives a broad equitable power to the courts, the Article II argument surely does not work as well, as Justices O'Connor and Kennedy must have realized. Technically speaking, then, the protest and contest phases raised different legal issues, but since everyone could see that this was the same election and the same issue about manual recounts, the Court failed to provide a generally understandable and coherent account of the federal constitutional basis of presidential election law. 
chance to take on board the last set of changes. And while it is disturbing that a common law system generally effects changes in cases in which the litigants might not have fully foreseen what the law is before the decision, it is doubly disturbing that the same set of litigants should have this happen twice in two weeks, when the whole legal framework for the election was rewritten and the litigants were instructed to go back to square one. In this sequence of decisions, the rule of law seems to have been one of the major losers.

\section{B. Legal Impossibility}

All of the participants involved in the Election 2000 challenges knew they were working against a deadline. And while at first, all of the parties wanted to wrap up all challenges by the December 12 "safe harbor" date that would have given some protection to Florida's electors against challenge before the Congress, the firmness of that deadline came under closer scrutiny as it came closer in time. The Gore team had argued all along that the December 12 date was an instruction to Congress not to interfere with state processes for selecting electors as long as the process was regulated by laws passed before the election and all challenges under that law were wrapped up by that date. According to the Gore team, the "safe harbor" provision was not a mandatory instruction to the state, but instead an instruction to the Congress about how to treat a state's electoral votes. ${ }^{174}$ But the Bush team and the Florida Legislature argued that December 12 was a drop-dead date that, if missed, jeopardized the representation of Florida in the electoral college. In their view, 3 U.S.C. $\$ 5$ therefore imposed duties on the state to settle its electors by that date. ${ }^{175}$

${ }^{174}$ Brief of Respondents Al Gore, Jr. and the Florida Democratic Party at 21-28, Bush v. Palm Beach County Canvassing Bd., 121 S. Ct. 471 (2000) (No. 00-836), available at http://election2000.stanford.edu/briefforrespondentsgore.pdf.

175 Brief of the Florida House of Representatives and Florida Senate as Amici Curiae in Support of Neither Party and Seeking Reversal at 16, Bush v. Gore, 121 S. Ct. 525 (2000) (No 00-949), available at http://election2000.stanford.edu/ floridahousel.pdf ("The Florida Supreme Court has jeopardized Florida's participation in the Electoral College in disregard of this Court's prior admonition, clear legislative wishes, and the Florida Supreme Court's own prior decision."); Brief for Petitioners at 35, Bush v. Gore, 121 S. Ct. 525 (2000) (No. 00-949), available at http://election2000.stanford.edu/bush949brief.pdf ("Reversal of the decision below is essential to preserve the protections that Congress sought to confer upon the States through $\S 5$, to secure the certainty and finality of Florida's electoral process, and to ensure that Florida's electoral votes are accorded proper consideration in Congress."). 
In the per curiam opinion in Bush v. Gore, the December 12 "safe harbor" suddenly turned into a blockaded port. The Supreme Court, in effect, prohibited recount ships from exploring the waters beyond the safe harbor, even though the Florida Legislature had nowhere put into the law anything that indicated such a preference, and even though the Florida Supreme Court, while clearly hurrying to try to meet this date, had not indicated that it was a blockade date for them either if there were important considerations of fairness at stake. Other states had clearly gone beyond this date in the past and still had their electors uncontroversially recognized far later in the process than the "safe harbor" date of December 12. ${ }^{176}$ Suddenly, however, the December 12 date became an absolute deadline preventing the newly announced standards from being applied to the matter at hand.

This particular aspect of the Court's decision has few defenders even among those who otherwise broadly agree with what the Court did in Bush v. Gore. But the deadline was critical to the result; in fact, in large measure, the deadline was the result. The per curiam opinion announced an ambitious set of guarantees that Florida law had to ensure, and then said that time was up so that standards could not be formulated and applied in the case that provided the occasion for the change in the law.

This combination of the ambitious new standards and the miserly deadline created an impossibility problem. If the Gore team sought to follow the guidelines for creating a uniform set of counting

1i" Hawaii's slate of electors in 1960 was not picked until the eve of the Congressional vote counting, see GOP Expresses Rancor over Ruling; Lawmaker Threatens Ti Clorllengr Electors, N.Y. TIMES, Nov. 23, 2000, at A33, and 3 U.S.C. $\$ 15$ seems to contemplate that. As long as there is still only one slate of electors presented to the Cingress, it would take something extraordinary to fail to give deference to the state on the matter. Only a majority vote in both houses of the Congress could reject a single slate of electors coming from a state. Of course, Florida might well have gone on to hute ta' slates of electors, since the Florida Legislature was bent on ensuring that a late of electors go forward for Bush regardless of the outcome of the court decisions and subvequent vote-counting. But even then, there are procedures in 3 U.S.C. $\$ 15$ for coping with the congressional receipt of two competing slates of electors. The Election 2000 problems, however bizarre they may have seemed, did have a clear pulitical remedy. That political remedy located the solution in the dynamics of the new Congress, not in the Supreme Court. Given 3 U.S.C. $\$ 15$, there was absolutely no reason for the Supreme Court to step in and stop the election. The law had not yet run out. Both the Constitution in the Twelfth Amendment and federal law under 3 L,$S . C . \$ 15$ still defined what should happen next. It was left to Congress to decide, in the end, whether the recount procedures produced an adequate result, which would be determined in the Congress's judgment about whether to accept a particular slate of electors. The Supreme Court's decision preempted this congressional function. 
standards, it would miss the deadline. If it sought to meet the deadline, it could not create the standards. It was, at the time Bush v. Gore came down, impossible for the Gore team to satisfy simultaneously both legal requirements that the Court set out.

How can we think about what is wrong with this? Again, the ruleof-law jurisprudence of the post-horror constitutional courts provides some guidance. Particularly in soviet-style legal systems, these sorts of Catch 22 situations were not unusual. And it was precisely this sort of experience that has led post-horror courts to be on the lookout for impossibility situations in particular, using their powers to do the opposite of what the U.S. Supreme Court did. Rather than announcing standards that create new impossibility problems, constitutional courts typically use their powers of judicial review to say that an interpretation of law creating such impossibilities is in itself a violation of the rule of law. When law commands two contradictory things, the rule of law requires that the contradiction be removed. For a court to participate actively in the creation of such an impossibility seems, in comparative perspective, quite astounding.

\section{Settling the Election Without SetTling the LAW}

So, after all of this, what is wrong with the 2000 election? The sequence of court decisions, and particularly the final decision of the U.S. Supreme Court, raises serious questions about the rule of law. ${ }^{17}$

The appearance and disappearance of legal standards throughout the Election 2000 lawsuits was a clear sign of the law itself being used as a vehicle of abuse. The Florida election statute was clearly incomplete, and into the gaps jumped the political strategy of both the Bush and Gore camps, as well as the politically motivated discretion of public officials charged with important but incompletely regulated functions under the law. Gore could challenge the vote tallies precisely in the places where he was most likely to pick up votes while ignoring counties that might have had more votes for Bush, leading to the cynical view that Gore wanted not to count every vote, but to count every Democratic vote. But it was, apparently, not only a

${ }^{177}$ My argument here is not that the U.S. Supreme Court should have cited as precedent cases from the Hungarian Constitutional Court or the Slovenian, Polish, or German courts, though these other courts are far more likely to look to each other than the U.S. Supreme Court is to look beyond its own jurisprudence. One of the stabilizing aspects of the new constitutional jurisprudence is that constitutional courts across Europe do tend to know, understand, and make use of each other's jurisprudence. 
perfectly legal challenge under the statute as written but the only sort of legal challenge envisioned in the law. Additionally, in the absence of clear and specific standards for counting machine-punched votes, Gore could argue for those standards most favorable to himself-and whatever he argued would of course have been decried on the Bush side, even if the standards Gore proposed were completely reasonable.

Of course, it wasn't just Gore who was using the law to fit his own strategic purposes. Bush was able to use the legal ambiguity to litigate and stall and run out the clock while tying the Gore team up in legal knots. All the while, Bush was not taking steps available to him to fix the errors that he decried. Though the Bush team branded the fourcounty manual recounts as selective and unfair because they would leave legal votes for him uncounted elsewhere in the state, the power to fix the selectivity by filing challenges in the other counties was clearly in Bush's hand. But, of course, he did not want to use that power because it might not have benefited him politically. What did benefit Bush politically was dragging every legal challenge on every point out as long as possible. The uncertainty of the law and the repeated legal challenges that were necessary to sort out what the law was clearly benefited the person who held the advantage of the status quo.

Republican Katherine Harris, charged with supervising the elections, had to make her decisions under a statute that omitted any clear standards about what she might use as a legitimate basis for rejecting late returns. On a cynical view, she took this as blanket permission to reject anything that might operate against the candidate she preferred. In addition, without clear standards for the county canvassing boards to use in determining whether and how to do a manual recount of ballots, the various county canvassing boards could use the legal ambiguity to justify whatever it was that they wanted to do-count or not count, omit dimpled chads or not, as the case may be.

Badly drafted statutes do more than make the situations they regulate unclear; a statute as badly drafted as this one positively invites abuse. If all parties can be easily seen to be following their own selfinterest to the point where the question "Who won the election?" becomes impossible to answer without a reference to the candidate whom one wanted to win, it is not just the candidates' fault. The whole reason for having law to guide election challenges is precisely to provide a nonpartisan mechanism for resolving disagreements, and the nonpartisan character of the law is assured primarily because the 
framework is settled before a particular dispute has arisen. But when a statute fails this elementary test-fails to channel challenges in such a way that they can be resolved according to standards that are known to be in place before the election-then the rule-of-law justification for following the law in the first place disappears. The Florida statute did not make the election more predictable, orderly, and fair. In the end, it prevented the predictable, orderly, and fair resolution of the election. Election 2000 turned into a legal free-for-all, with the various court challenges being used alternatively as harassment of the opponent and as political theater.

Both George W. Bush and Al Gore could be forgiven for having no idea about how the various court decisions would come out in Election 2000, given the incrementalist nature of the claims and responses from various courts. And Bush and Gore could be forgiven for thinking that the end result depended more on the political affiliations of the judges that heard the cases than it did on the law.

Part of what gripped the millions of us who were glued to our televisions during those thirty-six days was precisely the sense of unpredictability that resulted as one court ruled for Gore, and then the next court, accepting very different legal arguments, ruled for Bush. One of my colleagues compared the post-election court decisions to the opening scenes of Raiders of the Lost Ark. ${ }^{17 x}$ Just when Indiana Jones, the swashbuckling anthropologist-hero in that movie, had escaped from one heart-stopping threat, another one came-and then another and another to the point where the abnormal became normal. The election made for great television. It made for very bad law.

What we all saw during those thirty-six days was an American example of law abuse as both parties got as good as they gave in the self-interested attempt to make the most of a law that failed to constrain them at nearly every crucial turn. Both the Bush and Gore camps were whipsawed back and forth in state court, federal court, on trial and at appeal, through stays and reversals, new remedies, and new standards. Since the Florida election statute had a variety of unfortunate gaps, politics appeared to plug the gaps, which should have instead been plugged with principle. Both Al Gore and George W. Bush were caught up in a no-win game of legal formality and "you can't get there from here" arguments played with the highest stakes imaginable. Trapped inside a bad statute which contained neither the

178 RAIDERS OF THE LOST ARK (Metro-Goldwyn-Mayer 1981). 
explicit language nor the conceptual resources to deal with the situation that arose in the specific election, the candidates and the voters apparently became dependent instead on the partisan political preferences of the judges. And the legal ambiguity gave judges plenty of room to hang their own political preferences out on public display.

The rule-of-law principles revealed by a comparative constitutional analysis promise a way out of this. When confronted with a statute full of gaps and contradictions, a court should not try to pretend that the statute is not a problem and should certainly not put more weight on it than it can bear with literal interpretation. Instead, a court committed to the rule of law needs to examine the principles that animate the statute in light of the broader legal framework beyond the specific statute. In addition, a court should consider as well the expectations both of the litigants and also of the broader community which will have to live with the decision that the court's intervention ultimately produces. At a time like this, a judge has the responsibility to eschew a formalist approach to the statute in the name of the rule of law. But a judge also has the responsibility to prevent her own decisions from increasing the uncertainty and arbitrariness of the law. Decisions that whipsaw the litigants back and forth and decisions that require the impossible invite skepticism about courts.

In post-horror countries, where constitutional courts know fullwell how easy it is to slide into law abuse and are therefore constantly on guard against it, it is hard to imagine that this set of decisions would have been produced. ${ }^{179}$ The statute may have been severely flawed, but the sequence of court decisions, and particularly the decisions of the U.S. Supreme Court, which kept changing the legal frame, made matters worse.

The answer that should have emerged here was not difficult to discern in light of constitutional norms that would have been relatively easy to explain to a broad public. For one thing, the rights at stake were not the rights of the candidates, but instead the rights of the voters. And what is the substance of those rights? The substance is quite close to what the per curiam decision in Bush v. Gore said it was: the right to vote is a fundamental right that, precisely because it is fundamental, is subject to equal protection principles. That sort of

"15" One other crucial institutional difference, however, is that continental legal systems typically concentrate the power of judicial review in a single constitutional court, while the American power of judicial review is theoretically available to any court. The concentrated system of judicial review means that it is clear who bears the responsibility for ensuring that the big picture of constitutional claims is in view. 
analysis could have produced an early constitutional framework along the lines of "count all the votes, but count them equally." Gr" Gore would have gotten his request to count the votes, but Bush would have gotten the guarantees that such a count would not be weighted in favor of those voters from whom Gore thought he could extract the most support. Such a principle, announced either by the Florida Supreme Court or the U.S. Supreme Court early on, would have gone a long way toward settling the election by setting up a framework that did not simply seem to pick a specific result. It would also have saved the rule of law. "Count all of the votes using the same standard" would have meant supplementing Florida's defective statute with more stabilizing constitutional principles rather than construing the statute literally and therefore compounding the uncertainty. Ensuring equal protection would have kept voters' rights in view and would not have allowed them to get lost in the unbridled discretion of state officials (including not only the Secretary of State, but also the canvassing boards) or in the self-serving strategies of both campaigns. Such a decision would have, in the longer run, tied legality to legitimacy, though it would have come at the expense of following the statute literally. The whipsawing of the voters and the candidates, and the television drama that showed endless shocking twists and tums, should have been a sign that the election law itself was unstable because it was capable of being filled with completely partisan content. And a responsible court should have determined at the first possible opportunity that a defective statute that affected the rights of voters needed to be supplemented by the articulation of a constitutional framework for resolving the election that did not seem to be so nakedly choosing sides.

In the early days of recounting, no one knew how a statewide recount would have turned out. It therefore would have been harder to complain that a statewide recount would favor one candidate or another precisely because the result was unclear. It also would have been harder to complain that determining the election by a count of the votes was somehow itself a partisan act. The longer things went on, and the more time there was for a strategic analysis of what sorts

${ }^{180}$ The Article II argument, if it were to play a role on this analysis, would have to accommodate the view that the federal Constitution, at least, could provide guidance that would supplement the statutory framework even if state constitutional law could not. From the fact that the U.S. Supreme Court's own involvement in the case was not questioned by the Article II defenders, I would assume that even they would have to acknowledge this. 
of counting rules in which sorts of counties benefited each candidate, the less possible it became for any court to announce any standard that would have been seen as reasonably nonpartisan. The more the concrete result could be seen in the standard itself, the more the standard seemed politicized.

In the end, what happened was the worst of all possible worlds. Not only was the Florida statute not saved through literal interpretation, but the whole election was finally decided according to legal standards that remain quite unclear. By hanging onto the view that the statute could and did provide all the answers until the last minute, the U.S. Supreme Court ensured that the crucial contest in Election 2000 was in practice decided according to no discernible law at all.

The standards the U.S. Supreme Court announced in Bush v. Gore not only could not guide Florida's recount because they came too late, but they were not even used to revise Florida's existing certified vote totals. Moreover, they were not used to guide any of the other states whose results were part of the election totals nationwide and which might have run afoul of the standards that the Court held were to be retroactively applied to Election 2000. Given the great difficulties in unscrambling the eggs that the certified vote total in Florida mixed together, it might have made good sense for the U.S. Supreme Court to announce that its decision in Bush $v$. Gore had a prospective effect only. After all, it was the twenty-second hour-literally-by the time the Court made its pronouncement, and the Court itself set ground rules that nullified the application of its own decision standards to any ongoing Florida recount effort in Election 2000. Still, the U.S. Supreme Court seemed bent on retroactive application.

In practice, the U.S. Supreme Court decision in Bush v. Gore applied neither retroactively nor prospectively. It simply stopped everything where it was on the night of December 12 . No more official vote counting occurred after that date; the election results in place on that night were eerily preserved, rather like the ruins of Pompeii after the volcano. America has since inaugurated a new president, a president who was deemed to have won the votes he needed in the Electoral College even though he did not win the popular vote nationwide. ${ }^{\mathrm{s} I}$ But by how many votes, exactly, did

2*1 According to the CNN News Wrebsite, Gore leads in the popular tally by some 539,947 rotes. Cable News Network, Election 2000 Archive, at http://www.cnn.com/ ELECTION $/ 2000$. 
George W. Bush win his slate of electors in Florida? That turns out to be a legally embarrassing question to ask.

Did he win by the 1,784-vote margin of election night? Or by the 300 -vote margin resulting from the automatic recount? Did he win by the 930 votes that he appeared to have won after the absentee ballots were counted? Or did he win by the 537-vote count of the official certification? Is there some other number that better accounts for the results? Or-and of course the question lingers-did he really win at all? ${ }^{182}$ If the votes had been recounted in Florida under the sorts of procedures that the U.S. Supreme Court outlined as constitutionally required, do we know for sure that George W. Bush would have won Florida's electoral votes? And is it constitutionally permissible to count any other number, given the rationale in the per curiam opinion? Were we really in such a rush to find out that we didn't really care so much about whether we got the answer right?

The U.S. Supreme Court, while it did not in fact explicitly rule that the Florida statute was unconstitutional, certainly strongly implied that the statute was constitutionally deficient. If Florida election law does have the constitutional infirmities that the Court's decision in Bush $v$. Gore pointed to, and if the retroactive logic of Bush v. Gore requires that those infirmities be fixed for Election 2000, then that leaves open the question of just what Florida election law is and was for Election 2000.

The statute is arguably constitutionally defective in many ways: First, it is arguably defective because of Statutory Infelicity \#1, where the statute apparently allows the Secretary of State to throw out late returns, even though there are no standards in the law for the Secretary to follow in doing so. Does the equal protection or due process analysis in fact require that there be clear standards to guide the exercise of the Secretary of State's discretion so that votes in different parts of the state are not treated differently? (This may bear on which votes get to stay in the certified totals now.)

Second, the statute is also arguably defective because of Statutory Infelicity \#2, where the statute provides for manual recounts, but makes no adjustment in the deadlines for submitting vote tallies, thus making it harder for manual recounts in large counties to be carried

${ }^{182}$ After the election, there were clearly groups that felt that the election had been unfairly decided. The protests at George W. Bush's inauguration, the lingering suspicion in the black community that its votes hadn't been counted and the ongoing anger of at least some Democrats toward the new administration show it. One more humorous sign of the discontent was the "Re-elect Gore in 2004" bumper stickers. 
out on time when smaller counties might be able to accomplish the task. That would invite the equal protection challenge that votes in smaller counties would receive more careful attention and more checks than votes in larger counties. (This may lead to reconsidering whether Miami-Dade voters were discriminated against because they were in a large county that could not finish the recount back in the protest phase, long before December 12.)

Third, it is arguably defective because of Statutory Infelicity \#3, where the statute makes no provision for statewide challenges in statewide races, even though it is only through statewide challenges that one can build in mechanisms for ensuring that the same standards are used for recounting in an election that occurs in all counties. (This raises questions about whether Volusia and Broward Counties should be included in the certified vote totals if there was no more counting to be done after December 12.)

Fourth, it is arguably defective because of Statutory Infelicity \#4, where the statute makes no provision for treating federal elections and their special deadlines any differently from state elections which have different time constraints. There are no expedited procedures under the Florida statute that would allow election contests to be fairly resolved under the federal deadlines, making virtually any remedy the statute provides likely to be unusable for the election of presidential electors in particular. And that further leads to a legitimate concern that voters have more guarantees of accuracy in vote-counting when it comes to any election other than the one for presidential electors. Does the equal protection logic stop at presidential electors, or does the provision of more protections for the vote-counting in one sort of election than in another raise new equal protection problems? Could someone argue an equal protection (or perhaps a due process) violation because her vote for presidential electors received fewer guarantees that it would be equally counted than, say, her vote for Florida's national senators? (This raises broader questions about whether there has been a due process denial because all of the remedies were speeded up and then ultimately abandoned in the presidential race.)

Fifth, the Florida statute is probably most explicitly defective in the view of Supreme Court's per curiam opinion because of Statutory Infelicity \#5, where the statute gives state judges broad leeway to investigate complaints and set things right, without providing any standards for what counts as a legal vote or what counts as a constitutionally acceptable procedure for ensuring that all votes are 
given equal protection in the tabulation processes. There is, for example, no rule about hanging chads or specifying who is charged with carrying out recounts, both of which under Bush v. Gore now seem constitutionally required. (The Court focused particularly on the absence of consistent recount standards. But there were some recounts certified into the vote totals that were not conducted pursuant to any such standards. ${ }^{183}$ )

The Florida statute is potentially constitutionally defective in multiple areas and, as we have seen, each of these statutory infelicities played a substantial role in the recount battles of Election 2000 long before the December 12 deadline. And yet, the Supreme Court's decision in Bush v. Gore is supposed to be retroactive in its application so that it applies with full force to Election 2000. The United States has a national result in this presidential election that depended crucially on a legal determination of Florida's vote totals. So then we are left with a troubling question: What was the constitutionally valid Florida election law under which Florida's presidential electors were selected in 2000? From the chaotic ending of the recounts on December 12, it appears that we know neither what the right numbers are in Florida's vote totals nor what the law is under which we should determine what they are.

The problem is multiplied when one looks across the United States. Given that the "intent of the voter" standard was found in the Florida context to provide insufficient guarantees of fairness in the vote counting, does this mean that all of the states that used an intent of the voter standard in their vote tallies are now in constitutional trouble? Should there have been adjustments to the vote totals of other states, in order for the American election to be decided according to the constitutional standards spelled out by the per curiam decision in Bush $v$. Gore in its retroactive application to Election 2000? Or does Bush v. Gore apply only to the case of Florida, leaving the other states' laws untouched even though they might have had the same constitutional troubles in the same election? And what sort of equal protection is it that applies federal constitutional standards in one state only? In general, the usual understandings of Article III find no constitutional problems with resolving some concrete disputes without resolving all of the others that are logically

${ }^{183}$ Even on the narrow reading of what the Court required-that equal protection standards only applied to court-ordered recounts-the Broward County recounts that were certified were done exactly according to a Florida Supreme Court judgment telling them to continue counting. 
connected. But a national election raises special questions because the results of all of the states have to be added together to produce a single result, and having some states count votes one way and other states count votes another way raises more complex issues about what the relevant unit of "the case" is.

The confusion over what law decided Election 2000 raises more questions: Is George W. Bush a president who came into office by operation of the law-or without benefit of law? Or is the only relevant law under which he became president the single baremajority decision of the U.S. Supreme Court itself announcing that the election was over in the moment when the decision was made, giving force to a status quo that may or may not have been achieved according to the standards that justified stopping the clock?

Americans cannot look too closely at the law that decided the 2000 presidential election, because it isn't there. And that is perhaps the most damning commentary on the rule of law for Election 2000 in America. In the end, the Knights Who Say Either "NI!" or "Neeeow ... wum ... ping!" depending on how many of them decide to speak in chorus, thought it was more important to settle the election directly than to settle the law. 
